
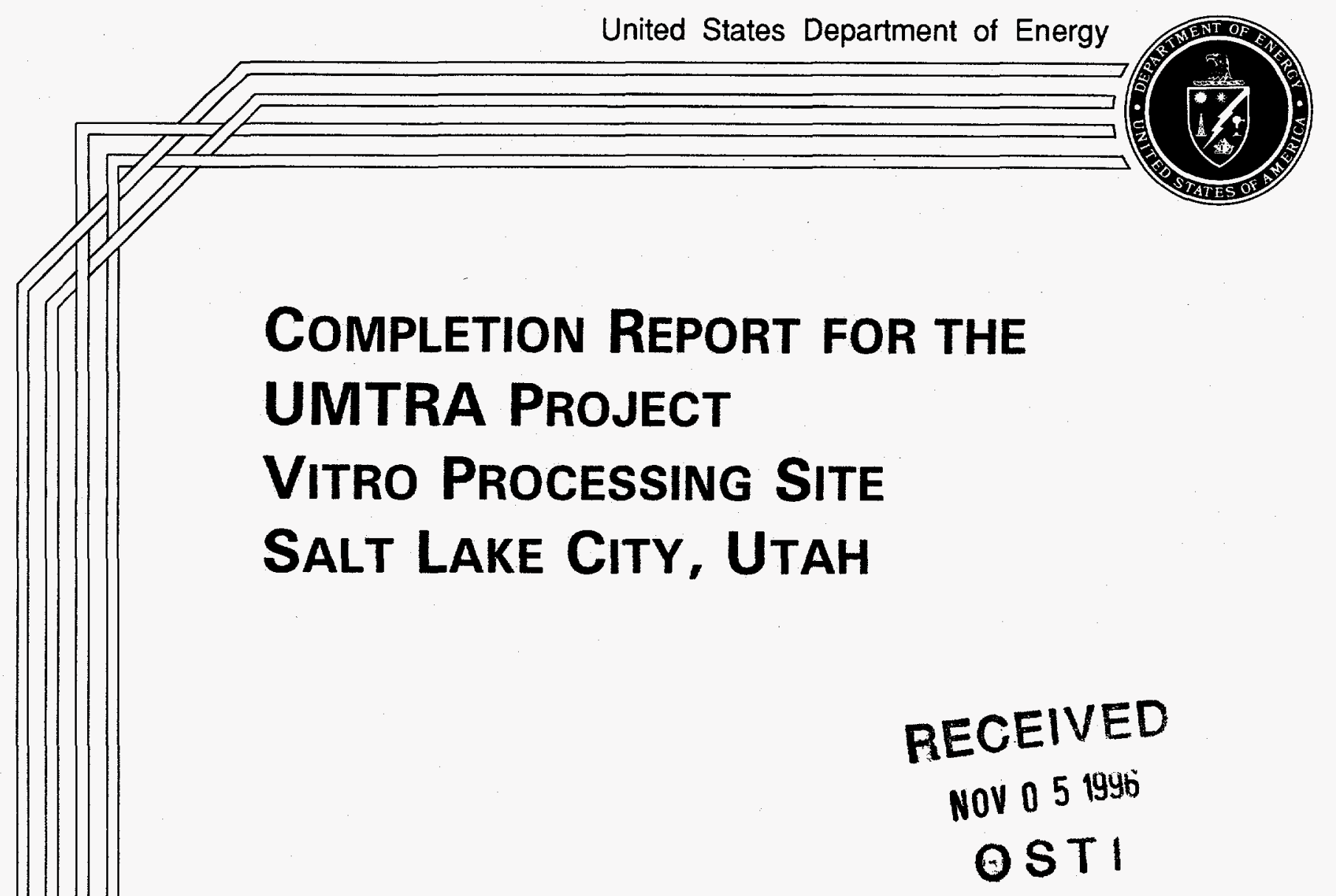

August 1996 


\title{
COMPLETION REPORT FOR THE \\ UMTRA PROJECT VITRO PROCESSING SITE \\ SALT LAKE CITY, UTAH
}

August 1996

\author{
Prepared by \\ State of Utah \\ Salt Lake City, Utah
}

\author{
Prepared for \\ U.S. Department of Energy \\ UMTRA Project Office \\ Albuquerque, New Mexico
}

\section{DISCLAIMER}

This report was prepared as an account of work sponsored by an agency of the United States Government. Neither the United States Government nor any agency thereof, nor any of their employees, makes any warranty, express or implied, or assumes any legal liability or responsibility for the accuracy, completeness, or usefulness of any information, apparatus, product, or process disclosed, or represents that its use would not infringe privately owned rights. Reference herein to any specific commercial product, process, or service by trade name, trademark, manufacturer, or otherwise does not necessarily constitute or imply its endorsement, recommendation, or favoring by the United States Government or any agency thereof. The views and opinions of authors expressed herein do not necessarily state or reflect those of the United States Government or any agency thereof. 


\section{DISCLAIMER}

Portions of this document may be illegible in electronic image products. Images are produced from the best available original document. 


\section{EXECUTIVE SUMMARY}

This completion report provides evidence that the final Salt Lake City, Utah, processing site property conditions are in accordance with the approved design and that all U.S. Environmental Protection Agency (EPA) standards have been satisfied. Included as appendixes to support the stated conclusions are the record drawings; a summary of grid test results; contract specifications and construction drawings and the EPA standards 140 CFR Part 192); the audit, inspection, and surveillance summary; the permit information; and project photographs.

The principal objectives of remedial action at Salt Lake City were to remove the tailings from the former processing site, render the site free of contamination to EPA standards, and restore the site to the final design grade elevations.

The final remedial action plan, which is approved by the U.S. Department of Energy and concurred upon by the U.S. Nuclear Regulatory Commission and the state of Utah, contains the conceptual design used to develop the final approved design. During remedial action construction operations, conditions were encountered that required design features that differed from the conceptual design. These conditions and the associated design changes are noted in the record drawings.

All remedial action activities were completed in conformance with the specifications and drawings. In the opinion of the state of Utah, the record drawings accurately reflect existing property conditions at the processing site. 


\section{TABLE OF CONTENTS}

Section

EXECUTIVE SUMMARY ES-1

1.0 INTRODUCTION

2.0 PROCESSING SITE DESCRIPTION

3.0 REMEDIAL ACTION PLAN, U.S. ENVIRONMENTAL PROTECTION AGENCY STANDARDS

4.0 CONSTRUCTION PROCESS DESCRIPTION

5.0 VITRO PROJECT ENVIRONMENTAL MONITORING AND HUMAN PROTECTION

5.1 Human protection.................................................................. $5-1$

5.2 External dosimetry.................................................................... $5-1$

5.3 Protective clothing................................................................. $5-1$

5.4 Personnel contamination monitoring ................................................. $5-2$

5.5 Access control .......................................................................... $5-2$

5.6 Occupational exposure to radioactive particulates.................................. $5-2$

5.7 Environmental monitoring ......................................................... $5-3$

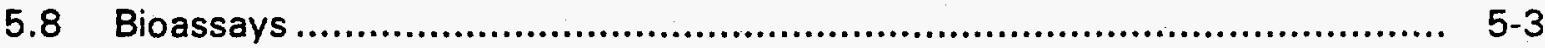

5.9 Certification sampling method .................................................. $5-3$

5.10 Permits, titles, and statements of compliance..................................... $5-5$

5.11 Delta measurement system ..................................................... $5-5$

5.11 .1 Equipment used................................................................. $5-5$

5.11 .2 Instrument setup ......................................................... $5-6$

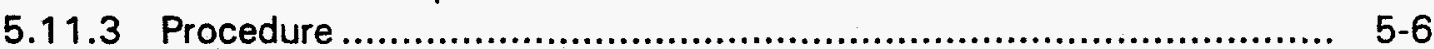

5.12 Ra-226 concentrations for backfill............................................... $5-8$

5.12 .1 Backfill sources .......................................................... $5-8$

5.12.2 Documentation backfill concentration levels ........................... $5-8$

6.0 SUPPLEMENTAL STANDARDS FOR THE VITRO PROCESSING SITE................. $6-1$

6.13300 South Street interface ...................................................... $6-1$

6.2 Supplemental standards application for thorium-230 ........................... $6-2$

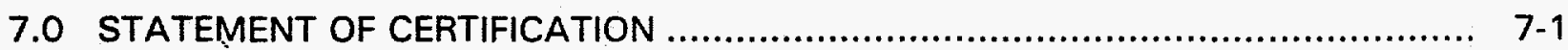

7.1 Regulatory contacts.............................................................. $7-7$

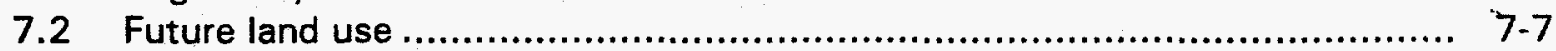

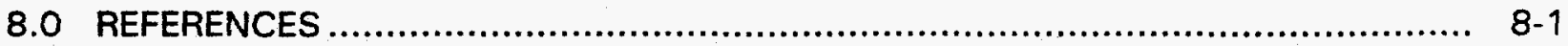


TABLE OF CONTENTS (Concluded)

Section

APPENDIX A RECORD DRAWINGS

APPENDIX B SUMMARY OF GRID TEST RESULTS

APPENDIX C CONTRACT SPECIFICATIONS

APPENDIX D 40 CFR PART 192

APPENDIX E AUDIT, INSPECTION, AND SURVEILLANCE SUMMARY

APPENDIX F PERMITS, TITLES, AND STATEMENTS OF COMPLIANCE

APPENDIX G PROJECT PHOTOGRAPHS 


\section{LIST OF FIGURES}

Eigure

Page

2.1 Land ownership and site designation map, Salt Lake City, Utah, Vitro processing site

5.1 Delta survey verification form

6.1 Thorium-230 sample locations and approximate depth to water during dewatering, Salt Lake City, Utah, Vitro processing site

7.1 Locations of Radium-226 contaminated areas, Salt Lake City, Utah, Vitro processing site

\section{LIST OF TABLES}

Table

5.1 Sample results for backfill ............................................................... $5-9$

5.21993 backfill concentration results.......................................................... $5-10$

6.1 Grids exceeding $35 \mathrm{pCi}$ per gram ...................................................... $6-5$

6.2100 -year radiation dose projections from selected thorium-230 grids.................. $6-9$

7.1 Grids that fail acceptance criteria or are missing data verifying cleanup conditions 


\section{LIST OF ACRONYMS}

Acronym

AASHTO

AEC

ALARA

ASTM

CVWRF

CVWRFB

DOE

DOE/AL

EIS

EPA

FBDU

ICRP

MDL

MK-F

NPDES

NRC

QA

RAP

RDC

SH\&B

TAC

TLD

UBRC

UBWPC

UDOH

UDOT

UDRC

UMTRA

UMTRCA

UOSHA

USHL

WL
Definition

American Association of State Highway and Transportation Officials U.S. Atomic Energy Commission

as low as reasonably achievable

American Society for Testing and Materials

Central Valley Water Reclamation Facility

Central Valley Water Reclamation Facility Board

U.S. Department of Energy

U.S. Department of Energy Albuquerque Operations Office

environmental impact statement

U.S. Environmental Protection Agency

Ford, Bacon \& Davis Utah

International Commission on Radiological Protection

minimum detectable level

Morrison Knudsen-Ferguson Company

National Pollutant Discharge Elimination System

U.S. Nuclear Regulatory Commission

quality assurance

remedial action plan

radon daughter concentration

Sergent, Hauskins \& Beckwith

Technical Assistance Contractor

thermoluminescent dosimeter

Utah Bureau of Radiation Control

Utah Bureau of Water Pollution Control

Utah Department of Health

Utah Department of Transportation

Utah Division of Radiation Control

Uranium Mill Tailings Remedial Action

Uranium Mill Tailings Radiation Control Act

Utah Occupational Safety and Health Administration

Utah State Health Laboratory

working level 


\subsection{INTRODUCTION}

In 1941, a large smelter was completed on 3300 South and 500 West in Salt Lake City. For 5 years this smelter was known as the Calunite Smelter, Inc. In 1946, the plant was known as the Vitro Chemical Company Calunite Plant. From 1941 through 1951, this smelter processed aluminum from aluminite. In May 1951, the Vitro plant began processing uranium ore under contract with the U.S. Atomic Energy Commission (AEC). The residual tailings produced in the process were deposited west and north of the plant. In 1959, the AEC authorized sale of the tailings, and about 100 off-site properties around the area used some of the tailings in their construction projects. The bulk of the tailings, however, remained at the Vitro site. Uranium ore milling discontinued in February 1964, and the vanadium ore processing began the next year.

By the time the Vitro mill operations terminated in 1968, the plant had produced 4787 tons (4343 tonnes) of concentrated yellow cake $\left(\mathrm{U}_{3} \mathrm{O}_{8}\right.$ ) and more than 4 million tons (3.6 million tonnes) of radioactive tailings. The mill facilities were dismantled in 1970 and the U.S. Environmental Protection Agency (EPA) began its survey of mill tailings processing sites 2 years later.

As the uranium mill sites were studied, the EPA became aware that the radioactive tailings posed a threat to public health. Thus, the following actions occurred regarding passage of a bill in Congress for the cleanup of the Vitro site:

- In March 1974, the Joint Committee on Atomic Energy conducted hearings on mill tailings cleanup programs.

- In April 1974, the Salt Lake City-County Board of Health declared the Vitro site a "public health hazard" because of the large concentrations of radioactive material. In April 1974, the Salt Lake City-County Board of Health established an 0.5-mile (mi) (0.8-kilometer [km]) construction ban around the site.

- In May 1974, Phase I joint surveys were conducted to locate off-site radioactive concentrations.

- In May 1974, the Energy Research and Development Administration awarded a contract to Ford, Bacon \& Davis Utah (FBDU) for the Phase II study report.

- In April 1976, FBDU published the Phase II report, which indicated a need for remedial action at the Vitro site and 160 identified vicinity properties.

- In May 1978, the Bureau of Radiation and Occupational Health confirmed radon levels at the Salt Liake County Fire Station No. 1 were unacceptably high.

- In June 1978, the Salt Lake City-County Health Department urged immediate relocation of firefighters from Salt Lake County Fire Station No. 1.

- In June 1978, the Salt Lake County Commission sent a resolution to Washington, D.C., declaring the emergency nature of Fire Station No. I and the Vitro mill tailings site. 
- In June 1978, the Salt Lake County Commission sent county officials to Grand Junction, Colorado, to investigate federal remedial action efforts of the Colorado mill tailings.

- In November 1978, Congress passed the Uranium Mill Tailings Radiation Control Act (UMTRCA) (42 USC $\$ 7901$ et seq.), requiring remedial action of identified mill tailings sites and off-site locations.

- In December 1979, the U.S. Department of Energy (DOE) designated the Vitro site for remedial action and the EPA began the process of drafting standards for that action the next month.

By June 1980, the state of Utah selected Clive, Utah, as the site to which the tailings would be moved. The DOE released a remedial action concept paper for the Vitro mill tailings in June 1981. In this paper, the DOE recommended removing the mill tailings to a suitable rural location. The Utah Department of Health (UDOH) issued its position paper on the Vitro site in March 1982, calling for removal and stabilization of the tailings in a suitable rural location, and labeling the tailings a health hazard. During the next month, the option of on-site stabilization instead of removal was considered. The DOE reversed its previous position in favor of on-site stabilization. The Uranium Mill Tailings Task Force voiced unanimous opposition to on-site stabilization in favor of removal. The Salt Lake County Commission and the Salt Lake County Council of Governments passed unanimous resolutions opposing on-site stabilization. U. S. Representative Dan Marriott of Utah publicly opposed on-site stabilization and the EPA delayed promulgations of remedial action standards. In May 1982, the DOE agreed to amend the remedial action concept paper regarding the proposed option of on-site stabilization. In January 1983, the state of Utah issued a position paper calling for removal of the Vitro tailings to Clive, Utah, and the DOE issued a draft environmental impact statement (EIS). The DOE conducted public hearings on the draft EIS in March 1983, and the state of Utah issued an economic impact report of remedial action proposed by the DOE. Finally, in April 1983, the DOE issued a contract to Morrison Knudsen-Ferguson Company (MK-F) for the first phase of the mill tailings cleanup project.

The first phase involved moving off-site tailings used in various area construction projects back to the Vitro site for removal to the Clive site in the western desert. The state of Utah had to purchase some of those vicinity properties, as they were called, to accomplish removal, and some property owners were relocated during removal and reestablished after cleanup.

While vicinity properties were being cleaned up, the Salt Lake County Commission initiated a water quality study. FBDU completed a Vitro hydrological study (Hintze, 1975). Sergent, Hauskins \& Beckwith, now named AGRA Earth and Environmental (AGRA E\&E) completed a seismic study of the Vitro site (SH\&B, 1983). Jacobs Engineering Group Inc. issued a final EIS of the remedial action option (DOE, 1984a), which confirmed shallow aquifer contamination and shallow deep aquifer interconnection. The chief hydrologist confirmed the probability of a deep aquifer contamination if the deep aquifer were extensively drained.

By August 1983, the state of Utah developed its cost estimate for the project at $\$ 49$ million for stabilization and $\$ 46.5$ million for removal. A meeting in September finalized the 
comments on the draft EIS. The draft EIS continued to propose stabilization in place as the most viable option for remedial action at Vitro. The state of Utah opposed that proposal and in early 1984, the DOE decided to allow the state to design and manage construction of the project at a cost not to exceed the stabilization estimate.

The UDOH and Utah Department of Transportation (UDOT) developed a memorandum of understanding to allow the UDOH to use UDOT resources in developing final design and providing field management. The final draft on the EIS was completed and generic work on the final design for the project began. In October 1984, the record of decision on the EIS was published and the DOE published the final remedial action plan (RAP) (DOE, 1984b). No technical design-supporting document was developed. By mandate, the design was based solely on the RAP.

Plans and specifications were offered for sale to prospective bidders in November, and bids were opened in December 1984 for remedial action construction. The contract was awarded in January 1985 to the Argee Corporation to perform the tailings removal; the first tailings left Salt Lake City for Clive in Tooele County by rail on 2 July 1985.

Over the next 11 months, 90 percent of the tailings were removed. In December 1986, the state of Utah directed the Argee Corporation to terminate work on the project, which was completed in March 1987.

To complete the project, the state of Utah issued a request for proposals in April, and the Tolboe Construction Company was awarded the contract in June 1987. The remaining 10 percent of the tailings were removed over the next 5 months, with the last load leaving on 20 November 1987.

In total, 4.3 million tons ( 3.9 million tonnes) of material were removed from the Vitro site. The 4.3 million tons (3.9 million tonnes) of material included all material in the embankment. A breakdown of general categories follows:

$\begin{array}{lrr}\text { Evaporation pond material } & 60,000 \text { tons } & (54,000 \text { tonnes }) \\ \text { Structural debris } & 32,000 \text { tons } & (29,000 \text { tonnes }) \\ \text { Vicinity property material } & 740,000 \text { tons } & (670,000 \text { tonnes }) \\ \text { Tailings } & 3,468,000 \text { tons } & (3,146,000 \text { tonnes }) \\ \text { Total } & 4,300,000 \text { tons } & (3,900,000 \text { tonnes) }\end{array}$

In the following months, the Clive disposal site was stabilized and completed with earth and rock protection in accordance with the design specifications. Environmental and safety monitoring were conducted throughout the entire process. Construction was also strictly monitored. Records for all monitoring were established and are on file with the DOE. 
Records can be obtained from the DOE, Albuquerque Operations Office, at the following address:

DOE/AL

P.O. Box 5400

Albuquerque, NM 87185-5400 


\subsection{PROCESSING SITE DESCRIPTION}

The Vitro site is located in the city of south Salt Lake in Salt Lake County, Utah, and is bounded by Mill Creek on the north, the Denver and Rio Grande Roper Railroad Yard on the east, 3300 South Street on the south, and 900 West Street on the west. The processing site is in the shape of a horseshoe. In the center of the horseshoe is Central Valley Water Reclamation Facility (CVWRF). The site is 128 ac (52 ha) total. Sheet 2 in Appendix C shows the location of the Vitro site in the Salt Lake vicinity and a schematic drawing of the site. The Central Valley Water Reclamation Facility Board (CVWRFB) owns all the property, including the CVWRF and the mill site. Figure 2.1 contains a legal description of the property boundary of the mill site.

The Vitro mill area was in the southeast corner of the site. The water table in this area is 1 to 2 feet ( $\mathrm{ft}$ ) $(0.3$ to 0.6 meter [m]) below the surface, making it very marshy and boggy. Directly west of the mill area is the storage area for vicinity property material (prior to its relocation to the Clive repositoryl. Directly north of the mill area is the load-out area, where ore was brought to the mill and yellow cake was taken from the mill. This ore yard had various levels of contamination. More tailings ponds were further west and further north of the mill area, around the west leg of the horseshoe.

Bisecting the site running south to north is a drainage ditch, referred to as the south Vitro ditch. A ditch running through the middle of the site from east to west is the old point of discharge for the sewage treatment facility located on the CVWRF; it is known as the Vitro ditch. (These ditches were relocated during remedial action.)

The entire site was sectioned off in $99-\mathrm{ft}(30-\mathrm{m})$ grids and subdivided into approximately $10 x$ $10 \mathrm{~m}$ verification grids. Each grid was tested in accordance with accepted standards for the DOE Uranium Mill Tailings Remedial Action (UMTRA) Project. Appendix B includes a summary of the grid test results.

During remedial action of both the CVWRF and the mill site itself, a multimillion dollar renovation was taking place on the CVWRF. The current point of discharge is in the northwest corner of the CVWRF, directly into Mill Creek. All services, including natural gas, power, sewer, and water had to be maintained for CVWRF during their operation and renovation. Also required at the CVWRF site was heavy equipment access to facilitate construction. Access was limited across the mill site because the CVWRF was bounded by Mill Creek to the north and no bridges crossed Mill Creek. Therefore, all services and access to the CVWRF had to cross the mill site during construction. As a result, tailings removal was scheduled in phases to allow continuous access to the CVWRF site.

Mill Creek was not contaminated and was not considered a part of the Vitro mill site or a vicinity property.

Thirty-third South Street and Ninth West Street are both major industrial access routes. These streets are heavily traveled and heightened the need for traffic control around the site. 


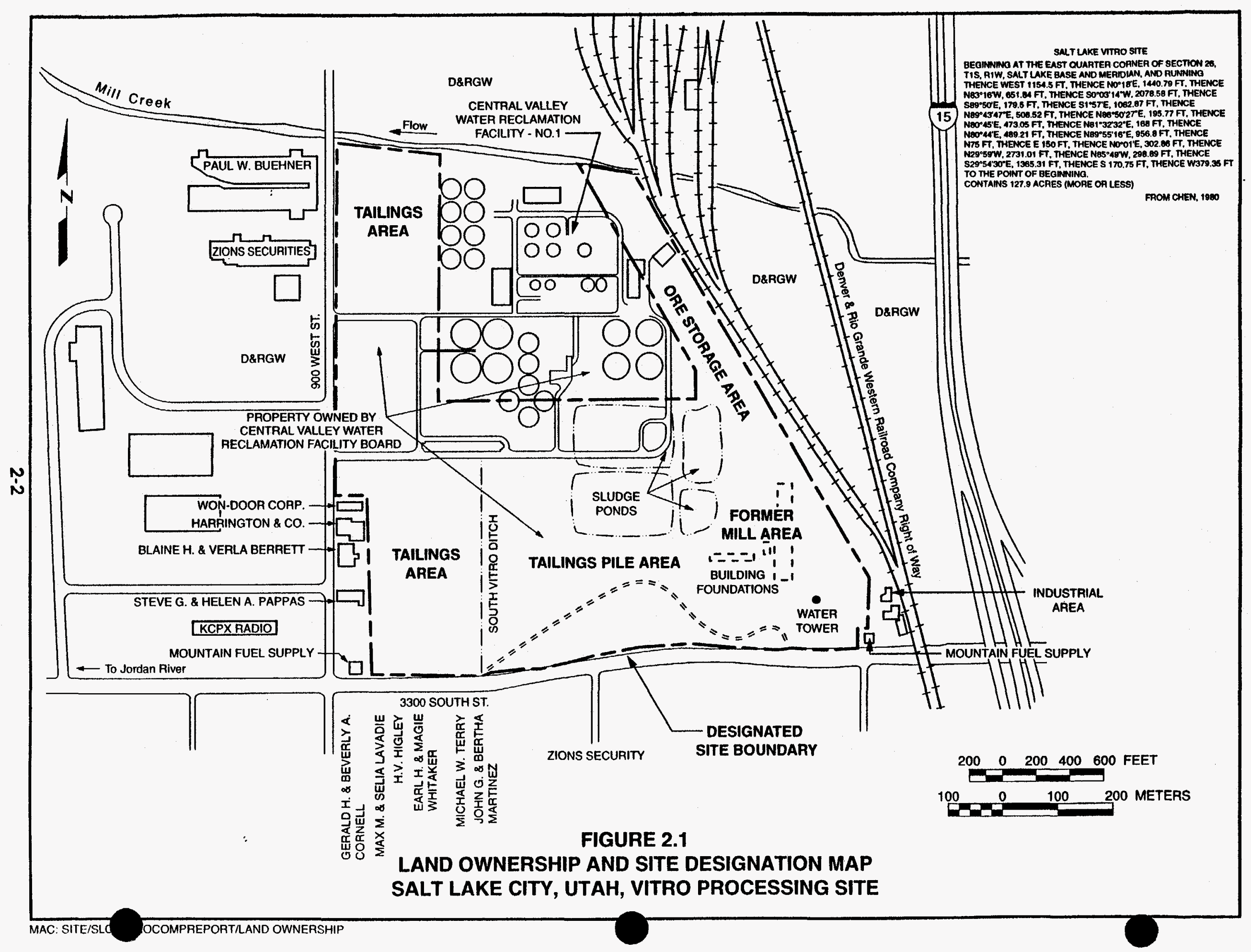


South and east of the sewer treatment facility were a series of sludge-drying lagoons. These lagoons were an active part of the sewer treatment operation and intermingled with the tailings. During remedial action, a storage area was maintained for sludge waste from the sewage treatment facility.

On the extreme southwest part of the site, running along Ninth West, were several vicinity properties.

The depth of the tailings on the site varied from $5 \mathrm{ft}(2 \mathrm{~m})$ to $35 \mathrm{ft}(11 \mathrm{~m})$, with an average depth of approximately $13.5 \mathrm{ft}(4.1 \mathrm{~m})$. The volume of structural debris was not as great as anticipated in the bid; however, several factors complicated the effort required to remove the debris. Structural debris was located in the area of highest ground water on the site; furthermore, all the structural debris, with very few exceptions, was heavily reinforced with large reinforcing steel rods. Finally, a number of structures were buried, which was not evident during removal of structural debris, requiring several remobilization efforts to remove the debris. Contaminated structural debris was encountered during the tailings removal process. Entire structure footing and foundations encountered during remedial action were removed. All known contaminated structures were removed in their entirety.

Drawing SLC-CL-021 (Appendix A) shows the master layout of the drawings used to verify the Vitro cleanup activities. Sheets $22,23,24,27,28,29,33$, and 34 all contain portions of the CVWRF on the respective drawings. All areas within the CVWRF are considered a vicinity property and were not part of the original Vitro site remedial action. Discussion of the cleanup of the CVWRF is found in the completion report for Vicinity Property SL-O67S (DOE, 1995).

The original drawings that characterized the site for bidding purposes placed a grid over the entire Vitro processing site property.

Two grid systems were used on the project. The site was divided by the Vitro ditch, which was a natural boundary. Separate grid coordinate systems were used for each section. The northwest portion of the site used the baseline B coordinate system; the balance of the site used the baseline A system. Both coordinate systems constitute the official grid layout. The grids directly north of the Vitro ditch relate to the $B$ coordinate system.

The daily delta measurement data sheets indicate when the tailings ran out before the grid ran out. As cleanup progressed, the grid areas expanded as necessary. Where rapid backfill was required, the drawings may not reflect the exact end of the excavation boundaries. If data are missing, it is usually because data were not needed. In some cases partial grids have been combined to verify cleanup for areas where tailings had been located. In most cases, delta work sheets reflect the end of the tailings but some of this information apparently was not transferred to the record drawings. This oversight may reflect the precision of the drawings, but except for specifically identified instances, cleanup was done in all areas of the site where contamination was found.

The drawings submitted with this completion report constitute the official record. Assurances that correct information is recorded on these drawings is inherent with the standard engineering practice of record drawings. 
Appendix $A$ includes a full set of record drawings. The drawings fully record the remedial action construction activities in response to the construction contract signed on 5 January 1985. A complete set of the original construction drawings is included as part of Appendix C. The specifications and construction drawings are part of Appendix C.

Comparing the construction drawings in Appendix $C$ with the record drawings in Appendix $A$ demonstrates the planned construction versus the actual performance of construction.

Comparing the record drawings with the RAP shows that remedial action to EPA standards promulgated for UMTRCA has occurred at the Vitro site.

Note that the record drawings are amended in their entirety regardless of whether they applied to the project. Some portions of the project were optional and the contractor chose not to perform them (e.g., the design of the half-diamond interchange on Interstate 80 for the truck option).

The following activities were completed at the old Vitro Chemical site after remedial action:

- The site was graded to the line requested by the owner.

- Surface ditches were relocated in accordance with owner approval.

- The site was seeded in accordance with the design specifications.

The site is fenced with an $8-\mathrm{ft}(2-\mathrm{m})$ chain link security fence. All gates are locked. The owner, CVWRF, controls access to the site. 


\subsection{REMEDIAL ACTION PLAN U.S. ENVIRONMENTAL PROTECTION AGENCY STANDARDS}

The final draft of the RAP was published in December 1984. The RAP listed EPA standards, introduced the project, characterized the site, and described the problem that existed at the Vitro site (40 CFR Part 192). The RAP also discussed a site conceptual design, environmental health and safety, responsibilities of project participants, maintenance and surveillance, and public participation. The RAP also presented information on the design at the Clive repository and the projected construction procedures. The RAP site conceptual design proposed two methods to transfer tailings from Vitro: hauling tailings by rail and by truck. The site characterization was brief but outlined the concerns and the problems that existed at the Vitro site with seismicity, ground water hydrology, and surface water hydrology; it also described the population surrounding the pile. The RAP included schedules, cost estimates, and a description of proposed work at the site. The RAP drawings included plot plans, utility drawings, and final site grading plans of the Vitro site. An extensive discussion regarding site drainage and water treatment was included in the appendixes.

The RAP provided the necessary documentation and, together with design calculations and the processing site characterization report, provided the state of Utah with enough information to perform final design and begin construction. The RAP also included EPA standards that outlined the requirements to be met by the remedial action project $140 \mathrm{CFR}$ 192) (Appendix D). All characterization used in the design, both radiological and hydrological, was obtained from three sources: the EIS, the RAP, and the site characterization presented in the original construction drawings. A set of contract specifications and construction drawings is included as Appendix $C$.

Characterization data from other studies performed at the Vitro site were used to develop the EIS and the RAP. These two documents are on file at the UMTRA Project Office in Albuquerque, New Mexico.

During the Vitro cleanup, the UBRC used the processing site characterization report (DOE, 1984c), dated December 1984, to obtain the background soil concentration information to verify soil cleanup. At 18 different locations the average radium-226 (Ra-226) soil concentration was determined to be 1.5 picocuries per gram ( $\mathrm{pCi}$ per gram) (in equilibrium with the natural uranium-238 [U-238]) (FBDU, 1981).

Section 4.2, page 14, paragraph 2, of the processing site characterization report references the January 1983 Bendix Field Engineering Corporation characterization (DOE, 1984c).

Ra-226 concentrations were $1.2 \mathrm{pCi} / \mathrm{g}$ averaged over 12 locations. The UBRC used $1.5 \mathrm{pCi} / \mathrm{g}$ $\mathrm{Ra}-226$ as the background for determination of adequate remediation. 


\subsection{CONSTRUCTION PROCESS DESCRIPTION}

This section outlines the actual construction process and how it was applied to the field, based on the specifications provided to the contractor. In January 1985, the contract was signed with the first contractor to complete remedial action at the Vitro site. By April 1985, mobilization and construction of the wastewater treatment facility began.

A wastewater treatment facility was installed to treat contaminated water produced by construction activities. The plant consisted of precipitation tanks that removed most solids. Final filtering used low-pressure, ultra-fine filtration with openings of 0.1 micron. The treatment plant was of modular construction and was relocated to Grand Junction, Colorado, for use on the UMTRA Project.

The contractor attempted to condition the tailings by a dewatering process. The tailings consisted of various types of soil such as clay, sands, grits, and other loamy material. Consequently, the tailings retained water and would not drain as the contractor had hoped. Dewatering renders a site constructible and has nothing to do with conditioning tailings. Therefore, a dispute arose and settlement was made in the spring of 1986.

Between April 1985 and July 1985, the site was controlled and fenced. Staging facilities and loading and unloading facilities were constructed and railroad spurs were installed.

On 2 July 1985, the first load of tailings was hauled to Clive. During the next 18 months the contractor employed a systematic approach to excavate the tailings. The contractor began in the extreme northwest corner of the site and proceeded south and east toward the staging facility, which was in the extreme southeast corner of the site. The contractor subcontracted the work for the structural debris removal that was ongoing during the project.

The UBRC provided excavation control following the sampling method below.

- Excavation continued until delta measurements on the floor of the dig indicated a clean condition. In cases of high background, a grab sample verified that the clean interface had been reached. The grid then was divided into nine equal sections. Using a small garden trowel, a sample was taken in the center of each of these sections to a depth of approximately 6 inches $(15$ centimeters $[\mathrm{cm}])$. The sample was put into a 5 -gallon (gal) (19-liter [L]) bucket and thoroughly mixed, resulting in a nine-plug composite sample. During the mixing process, all stones, sticks, building material, and other material larger than a pea were extracted. Approximately $\mathbf{5 0 0}$ grams of this composited sample were extracted and taken to the UBRC trailer on the site and canned. The samples then were analyzed for Ra-226 concentration.

- To verify the accuracy of the UBRC field analysis, the UBRC spilt samples with the UDOH laboratory. The UBRC determined the concentration of the sample before it was sent to the state laboratory. After the state laboratory determined the concentrations, the concentrations were compared to determine if the field results were in the same range. In addition, 1 sample in 50 was sent to the EPA in Las Vegas, Nevada, in a three-way split: one sample for the field analysis, one for the state laboratory, and one for the EPA. This 50-sample split was used to verify that the field laboratory as well as the state laboratory 
were getting the same results as the EPA laboratory. The comparisons between the state laboratory and the EPA gave the UBRC a high degree of confidence that all necessary tailings were removed. The UBRC results were almost always very close to the results of the other laboratories, but more importantly they almost always indicated higher levels of contamination than were determined by the other laboratories. For example, if field tests determined $2.5 \mathrm{pCi}$ per gram Ra-226, the EPA and the state laboratory indicated 1.6 or $1.2 \mathrm{pCi}$ per gram Ra-226.

- When grids were less than the standard size of approximately $10 \times 10 \mathrm{~m}$, the area tested always used nine composite samples spaced uniformly over the area. In some cases, two small grids were sampled at one time to achieve a standard sampling grid size; then nine samples were taken over the combined area. At no time were sampled areas larger than standard grid size.

Backfill was imported to the Vitro site from several sources. The principal source was a gravel pit at 4700 South Street and 6000 West Street, which had been identified in the original project documents. Supplemental backfill was imported from a Beck Street gravel pit at 2000 North Street and 1000 West Street. Excavation for the Primary Children's Hospital at the University of Utah supplied the additional material. Radiological measurements were taken periodically during the project to ensure acceptance of the imported material. Samples were evaluated to ensure normal background concentrations of all backfill material.

Material testing was conducted on the backfill to verify conformance of the gradation to the specifications (A-1-a through A-4 AASHTO designation M-145). Material was placed in 12inch $(30-\mathrm{cm})$ lifts and compacted to 90 percent of maximum dry density as determined by the American Society of Testing Materials (ASTM) Standard Proctor Method. When the natural clays were unstable, a thickness greater than 12 inches $(30 \mathrm{~cm})$ was permitted.

Some difficulties arose in coordinating efforts with the CVWRF to include access to the CVWRF and to control the waste sludge from CVWRF digesters, which had to be stored on the site. Another difficulty encountered was the treatment of the Vitro ditch and the south Vitro ditch. Both ditches required cleanup and drainage had to be maintained during the construction process. The difficulties described resulted in no impact to the quality or performance of cleanup at the site.

In November 1986, the contractor notified the state of Utah of completion of the quantities listed in the contract and the state of Utah released the contractor from any further obligation.

During the spring of 1987, the state of Utah negotiated a contract with the second contractor who was to relocate the remaining 10 percent of the tailings to the Clive repository. This area was in and around the staging area and comprised 250,000 cubic yards $\left(\mathrm{yd}^{3}\right)\left(190,000\right.$ cubic meters $\left.\left[\mathrm{m}^{3}\right)\right]$ of material. As noted earlier, ground water was highest in the southeast corner of the site. During the construction process, the contractor and the state of Utah maintained an extensive wash rack and site control. The second contractor hauled the tailings by truck to the Clive repository, which required a more extensive wash rack. The trucks were tarped and inspected before every haul. The train 
cars, however, underwent an automated washing process and a polymer fixative was applied to the top of the tailings to prevent dusting during the trip.

On 20 November 1987, the last load of tailings was hauled to the Clive repository. Section 7.0, "Statement of Certification," discusses site certification.

Some elevations were changed on each grid during construction. To explain the reasons for the changes, each elevation is defined below. The elevations shown in each grid map in Appendix A refer to the northwest corner. The top elevation refers to the existing elevation preceding construction excavation. The middle elevation indicates the excavated elevation. The bottom elevation indicates the final backfill elevation.

The elevations shown in the construction drawings (Appendix C) were developed as follows:

- Top elevation-An elevation given to the nearest tenth of a foot is the result of a field survey. An elevation given to the nearest foot is the result of an estimated value from an aerial survey.

- Middle elevation - This elevation was taken from estimated limits of contamination defined in the RAP. Because this elevation is an estimate, its value is shown to the nearest foot.

- Bottom elevation-This elevation represents final design grade as approved by the property owner (CVWRFB). Because this elevation is designed, its value is shown to the nearest foot.

Comparing the elevations shown in the construction drawings (Appendix $C$ ) with those shown in the record drawings (Appendix A) reveals the following differences in all elevation categories listed above.

- Top elevation-There are two reasons for differences in the few top elevations. First, every grid was surveyed using instruments rather than aerial survey. Second, construction involved cuts and fills on the site by the owner and others between the time the initial survey was conducted and the remedial action construction contractor mobilized.

- Middle elevation-This was merely an estimate. The final record elevation was established in the field during construction.

- Bottom elevation-The designed grade may differ from the actual final grade.

The locations of the Vitro ditches were not shown on the record drawings. During remediation, cleanup activities progressed closer to the Vitro ditches. In all cases, excavation was done as close to the ditch as possible without compromising the containment ability of the ditch bank. After verification activities, backfill was placed in areas previously excavated and final grade was established. At that time, a new ditch was excavated in the clean backfill material. The new ditch was as close to the old ditch as possible and ran parallel to the original ditch. When the new ditch was completed, the old ditch was diverted into the 
new ditch, leaving the old ditch and its banks available for remediation. Actual relocation of the Vitro ditches consisted of shifting the ditch bed a few meters in either direction. At the time the record drawings were being drawn, CVWRF had already relocated large sections of the ditches into culverts and backfilled them. The ditch locations were a moot point by the time the record drawings were finished.

Appendix E discusses the final audit report for the Vitro processing site (DOE, 1995a). 


\subsection{VITRO PROJECT ENVIRONMENTAL MONITORING AND HUMAN PROTECTION}

During the cleanup at the Vitro site in Salt Lake County and the subsequent move of material to the Clive disposal area, the UBRC instituted the Health, Safety and Monitoring Plan to protect the workers and the environment. A copy of the plan is available from the UBRC office in Salt Lake City, Utah. The plan is not detailed here, but an overview of the types of monitoring activities initiated by the UBRC are presented below.

\subsection{HUMAN PROTECTION}

Proper training of workers was considered essential to ensure safety. The UBRC health physics staff trained all workers involved in the actual removal of contaminated materials or working in any of the controlled site areas. Training included but was not limited to the following:

- Biological effects of radiation.

- Pathways for contamination.

- Control measures for limiting exposures.

- General safety.

- Smoking and eating policies.

Upon completion of the training, all personnel were tested to determine their understanding of the problems associated with working around radioactive mill tailings. Any person who did not pass the written test was retrained and retested. Each person had to demonstrate an understanding of the problems associated with working around radioactive materials before he or she was allowed to work on the site. In addition, personnel under the age of 18 were not permitted to enter or work in controlled areas.

\subsection{EXTERNAL DOSIMETRY}

Thermoluminescent dosimeter (TLD) badges monitored external radiation. All full-time personnel were issued TLD badges. A high turnover rate in the worker population hampered tracking radiation exposure for individuals. TLD results for construction personnel usually ranged below minimum detectable levels (MDL). Comparisons of TLD results for on-site UBRC staff and construction workers indicated that the UBRC staff were standing in the tailings most of the time during cleanup verification. The UBRC staff conducted continuous gamma surveys to ensure that exposure levels were at anticipated levels. Personnel monitoring records, including training records, were restricted to the UBRC office. All records were evaluated quarterly.

TLD measurements at the Vitro site were usually below the MDL and never exceeded standards set by federal or state laws or UMTRA guidelines. 


\subsection{PROTECTIVE CLOTHING}

All personnel were provided with protective coveralls and required to wear them in controlled areas of the site. Personnel were required to change from street clothes to work shoes and coveralls. Change facilities and laundry facilities were provided to ensure that contaminated gray water did not leave the site.

No personnel were allowed to leave the site with detectable contamination on their clothing or equipment.

\subsection{PERSONNEL CONTAMINATION MONITORING}

All personnel leaving the site were required to pass through a monitoring station equipped with alpha scintillation detectors, and they were required to wash their footwear and hands before leaving the site.

\subsection{ACCESS CONTROL}

Control points monitored access to areas of the site where contamination hazards existed. Signing in and out of the site was required. Access to the site was limited to personnel who needed to be on the site. Personnel who did not need to leave equipment or vehicles were required to stay in the cabs of the equipment they were operating.

Washing was required before any equipment, including transport vehicles (e.g., rail cars, trucks, and loaders), was allowed to leave the site. All equipment leaving the site for unrestricted use was washed to remove all visible material. Equipment then was surveyed by UBRC staff members to determine the levels, if any, of residual contamination: fixed, removable, etc. All survey information then was documented on a release form to verify compliance with all restriction criteria.

Road surfaces just outside access points to the Vitro site were swept routinely and soil accumulations were analyzed to ensure that contaminated material did not leave the site. Ramp areas from the wash rack and the railroad track bed were also sampled and analyzed for the same purpose.

\subsection{OCCUPATIONAL EXPOSURE TO RADIOACTIVE PARTICULATES}

Engineering controls and dust suppression techniques such as speed control, water use, and surface fixatives minimized airborne particulates levels.

Work areas were sampled daily; both worst-case and normal conditions were monitored. Samples were counted and quantified for gross alpha levels and compared with the thorium-230 (Th-230) limit established in 10 CFR Part 20. Occupational air monitors also were used to determine exposure to workers on the site. Hazardous materials in the air and respirable dust levels were monitored. Air sample analysis indicated the highest health risk was from silica levels in the dust rather than from radionuclides. Occupational exposures to radionuclides were well below the Th-230 
standard. Exposures to silica and other hazardous materials were maintained below levels of regulatory concern.

\subsection{ENVIRONMENTAL MONITORING}

Environmental monitoring efforts included monitoring radioactive and nonradioactive particulates in air and radioactive and nonradioactive contaminants in surface and ground water.

Air particulates were sampled continuously at points around the site boundary, primarily in the predominant wind direction. Samples were compared with Th-230 limits. Radon monitors using passive environmental radon monitors surrounded the site. The radon monitors were serviced by the UBRC staff and the EPA Las Vegas office performed the analysis.

Contaminated water, gray water, decontamination water, and runoff water sources were all channeled to collection areas and then pumped to the treatment plant at the northwest corner of the site. There the water was treated through an ion-exchange resin-treatment system and discharged into Mill Creek. Extensive monitoring of discharge flow and stream flow through the site, as well as of underground aquifers (through a network of wells around the Vitro site), verified that environmental impacts were minimized and well within required limits. Appendix $F$ includes a copy of the National Pollutant Discharge Elimination System (NPDES).

Permit and sample discharge monitoring reports were prepared, which outlined all discharge concentrations required by the Utah Bureau of Water Pollution Control (UBWPC) permits section.

An industrial hygienist from the Salt Lake City-County Health Department worked with the UBRC to address actual and suspected industrial hygiene concerns. Inspections by Utah Occupational Safety and Health Administration (UOSHA) included noise monitoring, chemical exposure, and transportation.

\subsection{BIOASSAYS}

Originally, a whole-body counting program was initiated for personnel working in the controlled areas of the site. At the end of the first year, the whole-body counts for all personnel who were counted indicated whole-body exposures had been maintained at background levels. Whole-body counting activities were discontinued for that reason because of logistic problems in accessing the whole-body counter at the University of Utah, and the high cost-to-benefit ratio for verifying background level exposures.

\subsection{CERTIFICATION SAMPLING METHOD}

At the start of the Vitro project, the UBRC looked at several methods for gathering soil samples. Methods used at other UMTRA locations were moving toward a 20sample composite grid and the Schiager bucket method. Sampling methodology used by the Technical Assistance Contractor (TAC) was very time consuming and the 
results did not appear significantly improved over the UBRC method. The UBRC sampling method is as follows:

- Excavation continued until delta measurements on the floor indicated a clean condition. After this clean-to-dirty interface was located using the delta measurement and a quick-grab sample, the final verification sample was used to verify clean.

- The grid was divided into nine equal sections. Using a small garden trowel, a sample was taken in the center of each of these sections to a depth of approximately 6 inches $(15 \mathrm{~cm})$. The sample was then put into a 5 -gal $(19-\mathrm{L})$ bucket and thoroughly mixed, resulting in a nine-plug composite sample. During the mixing process all stones, sticks, building material, and other material larger than a pea were extracted. Approximately 500 grams of this composited sample were extracted, taken to the UBRC trailer on the site, and canned. The samples then were analyzed for $\mathrm{Ra}-226$ concentration.

- To verify the accuracy of the UBRC field analysis, the samples were split with the Utah State Health Laboratory (USHL). The UBRC determined the concentration of the sample before it was sent to the USHL. After the USHL determined the concentration, the concentrations were compared to determine if the field results were in the same range. In addition, 1 sample in $\mathbf{5 0}$ was sent to the EPA laboratory in Las Vegas, Nevada; this sample was a three-way split, with one sample for the UBRC field analysis, one for the USHL, and one for the EPA. This 50-sample split was used to verify that the field laboratory as well as the USHL were getting the same results as the EPA laboratory. The comparisons between the USHL and the EPA gave the UBRC a high degree of confidence that all necessary tailings were being removed. The UBRC results almost always were very close to the results of the other laboratories but more importantly, they indicated higher levels of contamination than were determined by the other laboratories. If the field determination was $2.5 \mathrm{pCi}$ per gram Ra-226, the EPA and USHL would indicate 1.6 or $1.2 \mathrm{pCi}$ per gram Ra-226. No correction factors were established. The laboratory analysis was conducted to provide quality assurance (OA).

When grids were less than standard grid size, the area tested always used nine composite samples spaced uniformly over the area. In some cases, two small grids were sampled at one time to achieve a standard sampling grid size; then nine samples were taken over the combined areas. At no time were sampled areas larger than grid size.

The Vitro site had perched water pockets all over the clean-to-dirty interface. When excavation exposed areas where these conditions existed, leaving them generated ". large quantities of extra water. This water had to be treated as contaminated and pumped to the water treatment plant at the northwest corner of the property for treatment before being pumped into Mill Creek. Due to the expense of pumping water from areas of excavation to the treatment plant and treating the water, rapid backfill was very important. To facilitate the rapid backfill requirement, the UBRC needed a 
rapid turnaround time for soil analysis. Time taken to dry and equilibrate samples was very costly in terms of managing water. To save time, a safety multiplier of 2 was applied to the quick count. If without equilibration the drying of a sample was to be $3.5 \mathrm{pCi}$ per gram, worst case after equilibration was assumed to be $7 \mathrm{pCi}$ per gram Ra-226. Using this factor and the fact that results were conservatively high throughout the run of the project, the overall outcome is that virtually all of the areas were cleaned to levels below those established by the UMTRA Project (certain exceptions are discussed in Sections 6.0 and 7.0 of this report).

\subsection{PERMITS, TITLES, AND STATEMENTS OF COMPLIANCE}

The following permits normally are required for most environmental remedial action projects, although very few permits were required on the Vitro project. A summary of each permit follows (Appendix $F$ contains detailed permit information):

- NPDES permit for the wastewater treatment facility. State of Utah certification.

- Wastewater treatment facility construction permit. This permit was obtained through the shop drawing procedure during the administration of the contract.

- Air quality approval order. Not required under current state of Utah requirements.

- Approval of well plugging. No wells were plugged. Because the depth of excavation was in all cases greater than the depth of the existing wells, the wells were removed with the excavated material and no plugging was required.

- Approval to repair, clean, deepen, or replace an existing well. Not required.

- Review of flood control and drainage system modifications. Not required.

- Conduction review-noise estimate. Not required.

- City of South Salt Lake grading permit. Not required.

Grading and drainage concerns were discussed and handled through the remedial action agreement (RAA) with the property owner, CVWRFB.

\section{$5.11 \quad$ DELTA MEASUREMENT SYSTEM}

\subsubsection{Equipment used}

The equipment listed below was used during verification activities.

Model $12 \mathrm{~S}$ Micro R meter. Lead sheeting 0.125 inch (3.0 millimeters [mm]) thick. Lead plate $3 \times 7 \times 0.5$ inch $(80 \times 180 \times 13 \mathrm{~mm})$ thick.

Delta grid survey form. 


\subsubsection{Instrument setup}

The model $12 \mathrm{~S}$ Micro $\mathrm{R}$ meter was wrapped with a roll of lead sheeting to a thickness of 0.5 inch $(13 \mathrm{~mm})$. The wrapping covered all the sides of the meter in a continuous layer from top to bottom. The top of the meter was left open to read the meter and the bottom of the meter was left open to facilitate directional measurements from the underside. The shielding on the side of the instrument facilitated working in the high-shine environment adjacent to the cut face of the dig. During operation, the instrument was placed on the spot measured and the exposure rate was noted. Then 0.5 -inch $(13-\mathrm{mm})$ lead plate was placed under the instrument and the exposure rate was noted. Procedures for using the delta information follow.

\subsubsection{Procedure}

At the start of each shift, the technician on duty performed a consistency check for the instrument to be used. Background levels were verified and exposure levels from a known standard were measured to ensure proper functioning of the instrument. Then the technician checked delta measurements for known clean grids in the working area and determined approximate cutoff delta values in the same area. The technician proceeded to the area where grids were being cleaned. The technician followed the dig with the instrument and guided the removal of material using delta measurements to determine if cleanup had taken enough material from a given grid. When the technician was satisfied that the area was clean, a grab sample was taken and analyzed by a quick count to ensure that the clean interface had been reached. After confirming the correct depth of excavation, the survey team identified the grid location and marked the grid corners.

Then the technician completed a delta survey verification form (Figure 5.1) noting the name of the technician, instrument identification, date and time of the survey, source check information, and the map coordinates that identified the grid. After determining the nine sample locations for each grid, the technician performed delta measurements at each sample location. Soil samples were taken to a depth of 6 inches $(150 \mathrm{~mm})$ at nine locations per grid. The nine samples were mixed and an aliquot was analyzed to determine compliance with cleanup criteria.

Note that due to the variation in depth of dig and the proximity of the tailings piles, it was not possible to determine the delta cutoff level for the entire site. The cutoff delta is dynamic and was determined each day; the skill of the technician was the key to using deltas to guide the excavation at the project. Also note that delta measurements generally were used to guide the dig only. Soil samples were the primary verification accepted by the state of Utah. However, if collection of a soil sample was not possible, these delta measurements were used for verification purposes, as well. 


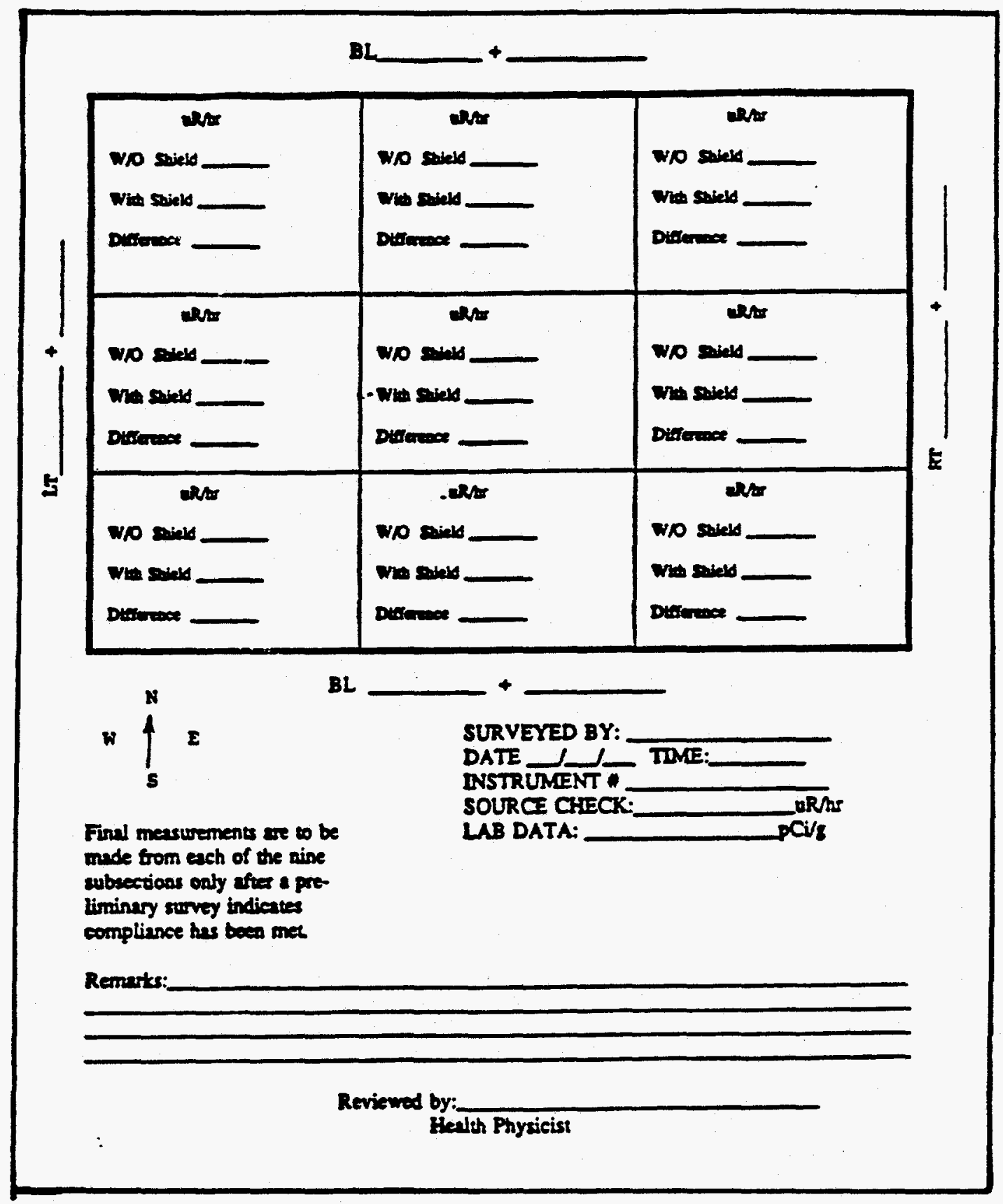

Figure 5.1 Delta survey verification form 


\subsection{Ra-226 CONCENTRATIONS FOR BACKFILL}

5.12.1 Backfill sources

Backfill used at the Vitro site was imported from several sources. The principal source was a gravel pit at 4700 South Street and 6000 West Street, which had been identified in the original project documents. Supplemental backfill was imported from a Beck Street gravel pit at $2000 \mathrm{~N}$ and $1000 \mathrm{~W}$. Excavation of the Primary Children's Hospital at the University of Utah supplied additional material.

\subsubsection{Documentation backfill concentration levels}

Prior to startup of the project, health physicists from the state of Utah visited the source pit for the backfill and performed a walkover survey of the pit. Then samples were taken of the material. Samples were analyzed by the UBRC opposed crystal system and verified by the UDOH laboratory. During the project, samples were taken periodically to verify that the soil concentrations were at background concentration levels. During the project, the UBRC maintained a separate log book for these samples. However, the original completion report review overlooked documentation of backfill soil concentrations. Subsequent searches for the record book containing backfill soil concentrations proved futile. A search of the count log record book shows that some backfill samples were counted in December 1986. Table 5.1 shows the backfill concentrations identified at that time.

Additionally, in June 1993, the Utah Division of Radiation Control (UDRC) staff members gathered 10 samples from random locations around the site and had them analyzed by the UDOH laboratory. Table 5.2 provides the sampling locations and results of analysis. 
Table 5.1 Sample results for backfill

\begin{tabular}{|c|c|c|}
\hline Date & Sample location & $\begin{array}{c}\text { Ra-226 concentration } \\
\text { (pCi/g) }\end{array}$ \\
\hline $12 / 11 / 86$ & Spot sample demag dig/ramp & 1.7 \\
\hline$"$ & Spot sample Zone 3 & 1.6 \\
\hline$"$ & Spot sample Zone 4 & 1.0 \\
\hline$"$ & Spot sample Zone 5A & 1.3 \\
\hline$"$ & Spot sample Zone 5B & 0.8 \\
\hline$"$ & Spot sample Zone $5 \mathrm{C}$ & 5.5 \\
\hline$"$ & Spot sample Zone 6 & 0.9 \\
\hline$"$ & Spot sample Zone 9 & 1.1 \\
\hline $12 / 15 / 89$ & Spot sample Zone 10 & 1.3 \\
\hline$"$ & Spot sample Zone 13 & 1.0 \\
\hline$"$ & Spot sample Zone 11 & 0.9 \\
\hline$"$ & Spot sample Zone 13 & 1.0 \\
\hline$"$ & Spot sample Zone 12 & 0.7 \\
\hline$"$ & Spot sample Zone 12 & 0.9 \\
\hline$"$ & Spot sample Zone 7 & 1.2 \\
\hline$"$ & Spot sample Zone 8 & 1.1 \\
\hline $12 / 16 / 89$ & Spot sample Zone 10 & 0.9 \\
\hline$"$ & Spot sample Zone 10 & 1.0 \\
\hline$"$ & Spot sample Zone 10 & 2.0 \\
\hline$"$ & Spot sample Zone 10 & 0.7 \\
\hline$"$ & Spot sample Zone 14 & 1.1 \\
\hline$"$ : & Spot sample Zone 12 & 0.9 \\
\hline$"$ & Spot sample Zone 12 & 1.2 \\
\hline$"$ & Spot sample Zone 8 & 0.9 \\
\hline
\end{tabular}


Table 5.21993 backfill concentration results

\begin{tabular}{ccccc}
\hline Date & $\begin{array}{c}\text { Sample } \\
\text { identification }\end{array}$ & Grid location & $\begin{array}{c}\text { Ra-226 UBRC } \\
\text { analysis } \\
\text { (pCi/gram) }\end{array}$ & $\begin{array}{c}\text { Ra-226 UDOH } \\
\text { laboratory } \\
\text { (pCi/gram) }\end{array}$ \\
\hline $5 / 17 / 93$ & A & $6+60 \mathrm{~N}-22+11 \mathrm{E}$ & 3.4 & 3.2 \\
$"$ & B & $11+55 \mathrm{~N}-16+50 \mathrm{E}$ & 1.3 & 1.1 \\
$"$ & C & $5+94 \mathrm{~N}-15+84 \mathrm{E}$ & 1.9 & 1.7 \\
$"$ & D & $5+94 \mathrm{~N}-9+90 \mathrm{E}$ & 1.3 & 1.2 \\
$"$ & E & $5+94 \mathrm{~N}-0+00$ & 1.5 & 1.4 \\
$"$ & F & $11+88 \mathrm{~N}-5+61 \mathrm{~W}$ & 1.2 & 0.9 \\
$"$ & G & $7+26 \mathrm{~N}-5+61 \mathrm{~W}$ & 1.2 & 1.1 \\
$"$ & H & $0+66 \mathrm{~N}-6+27 \mathrm{~W}$ & 1.0 & 1.0 \\
$"$ & I & $0+99 \mathrm{~N}-0+99 \mathrm{E}$ & 1.2 & 0.9 \\
& J & $1+98 \mathrm{~N}-17+82 \mathrm{E}$ & 0.9 & 2.0 \\
& K & Hot spot at Vitro ditch & 2.0 & \\
\hline
\end{tabular}

${ }^{8}$ Grid location is approximate. 


\subsection{SUPPLEMENTAL STANDARDS FOR THE VITRO PROCESSING SITE}

During the cleanup of the Vitro processing site in Salt Lake City, residual radioactive materials were not completely removed from various locations. Characterization of these areas and the problems associated with the remediation are discussed below.

\subsection{SOUTH STREET INTERFACE}

The south side of the Vitro site is bounded by 3300 South Street. This street had been widened and the right-of-way overlaps the edge of the tailings along parts of the south side of the site. Areas east of the right-of-way interface at $1+98 \mathrm{~N}-14+85 \mathrm{E}$, "Vitro Site Plan Drawing 0036," were cleaned using standard verification procedures. The cleanup of the interface with 3300 South Street, west of $1+98 \mathrm{~N}-14+85 \mathrm{E}$, was complicated in some locations due to underground utilities. The complications included an old 48-inch $(1220-\mathrm{mm})$ nonreinforced concrete storm drain and a 10-inch $(250-\mathrm{mm})$ high-pressure gas line. Both pipes were located at the interface of the tailings material and the right-of-way. The storm drain contained water at the time of excavation and began leaking when surrounding fill material was removed. Leaking and the stress caused by washout under the pipe necessitated immediate backfill when possible. The tailings material on top and on both sides of the storm drainpipe were removed. Material on which the pipe was resting had to be left in place to ensure pipeline integrity. Moving the pipe would have affected the stability of the road base under 3300 South Street. The high-pressure natural gas line parallels the drainpipe at the last $500 \mathrm{ft}(150 \mathrm{~m})$ of the right-of-way interface (going west).

The gas line is one of the major supply lines in the area and disturbing the pipe in any way could have caused a leak. After Mountain Fuel Company located the pipe for the contractor, tailings material was removed to within 18 inches $(460 \mathrm{~mm})$ of the pipe. Most backfill material around the gas pipe was not contaminated. However, hot spot areas exist along the gas line. The benefit of removing the contaminated material closer to the pipe, compared with the risks associated with moving the gas line, did not justify continued efforts.

The contaminated soil under the street and under the pipeline was mixed with road base, gravel, and native soils. The UBRC obtained several soil samples from contaminated areas and determined an average Ra-226 concentration of $30 \mathrm{pCi}$ per gram. The UBRC located the area of the highest exposure rate and sampled this material. Ra-226 concentration for this material was approximately $150 \mathrm{pCi}$ per gram. All on-site sample analysis used the opposed crystal system. Attempts were made to determine how far the tailings extended under the street. Indications are that, in some places, they may extend 2 to $3 \mathrm{ft}(0.6$ to $0.9 \mathrm{~m})$. Due to traffic problems and safety concerns, no test holes were drilled in the street. Tailings material was left in small pockets around the junction boxes, under the storm drainpipe, and around the gas line. The material under the storm drainpipe appeared to be only 1 to 2 inches $(20$ to $50 \mathrm{~mm})$ thick and mixed with native soils. All determinations were made by visual assessments of the material along the side of the excavation (looking south into the cut face), and by gamma surveys in the street. All the contaminated materials along 3300 South Street are at least $1 \mathrm{ft}(0.3 \mathrm{~m})$ below 
the surface of the road and in some cases at least $4 \mathrm{ft}(1.2 \mathrm{~m})$ under final grade. The tailings left along the right-of-way are not evenly distributed but are in isolated pockets, indicating random spillover from the main pile on the site. The contaminated material is dispersed along a 620-ft $(190-\mathrm{m})$-long excavation face and the total quantity left in place is estimated at less than $200 \mathrm{yd}^{3}\left(150 \mathrm{~m}^{3}\right)$.

Supplemental standards were applied in this area due to the risk of damaging the gas line, breaching the drainpipe, and collapsing the road base; danger from vehicles using 3300 South Street; and loss of westbound traffic lanes on a state highway. The state of Utah believes that leaving small pockets of tailings material along the right-of-way interface will not severely impact the safety of the public and the environment.

\subsection{SUPPLEMENTAL STANDARDS APPLICATION FOR THORIUM-230}

When the site was being cleaned up, it was thought that remediating the site for Ra-226 would include all other residual radionuclides associated with uranium milling in the cleanup process. Therefore, the cleanup effort at the Vitro site was targeted to meet Ra-226 standards. About the time site cleanup was coming to conclusion, the UMTRA Project determined that cleanup of Ra-226 did not necessarily mean the site was free of other radionuclides. On other UMTRA sites Th-230 migrated relative to $R a-226$. To determine whether $T h-230$ had migrated relative to $R a-226$ on this site, 50 archived verification samples were reanalyzed. Of these verification samples, 14 were found to have high Th-230 concentrations. Also, a percentage of verification samples collected were split and sent to EPA in Las Vegas for QC check analyses. These QC splits were analyzed for both Ra-226 and Th-230. Ten of these samples exceeded 50 pCi per gram (EPA minimum detectable activity levels for Th-230). Because only a fraction of the site was sampled for Th-230 the location of any Th-230 that might remain on the site can only be hypothesized. Therefore, the verification sample grids that have elevated Th-230 are grouped into 4 general areas. These areas are shaded on Figure 6.1.

Figure 6.1 identifies all the locations sampled for Th-230 (both elevated grids and nonelevated grids). Evaluation of the areas where elevated Th-230 was found shows that the Th-230 generally migrated from the Ra-226 in areas that were used as evaporation ponds or where ditches crossed the property. Th- 230 would be expected to migrate relative to the Ra-226 due to the relatively higher mobility of thorium compared to radium under the chemical conditions that existed in these areas. The Th-230 found in Area 1 is the only elevated Th-230 grid not associated with a known evaporation pond or ditch. It is not known why elevated Th-230 exists in this area. Because only one verification sample was analyzed for this portion of the site, it is very difficult to determine the extent of Th-230 contamination in this area. However, since most of the Th-230 was found in evaporation ponds and ditches only a small amount of Th-230 is thought to remain in this area. In all areas of the site where Th-230 has been identified, the extent of Th-230 contamination may extend beyond the specific grids for which data have 


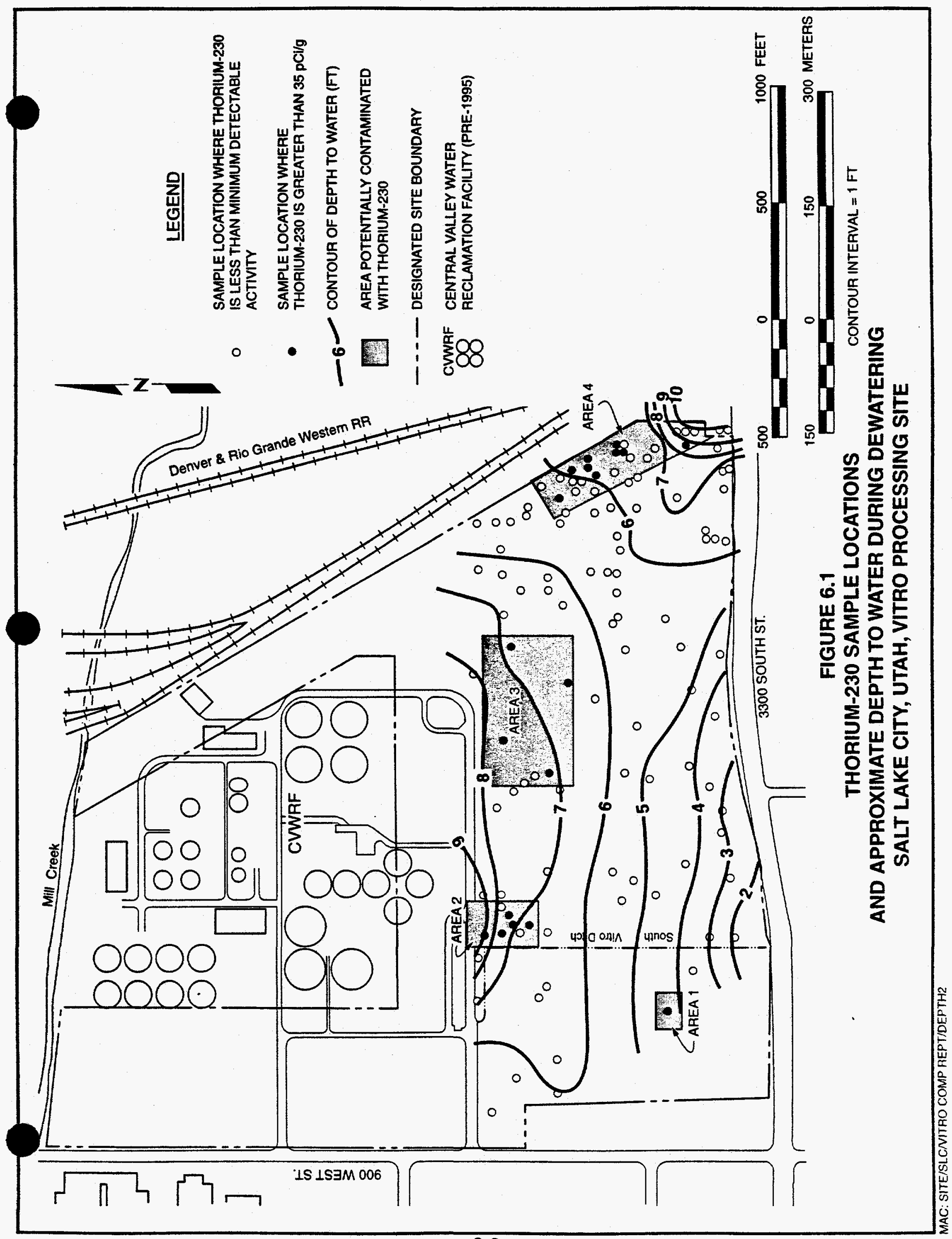


been collected. Future users of the site should note that any areas in the vicinity of known Th-230 contamination grids should be considered potentially contaminated.

Supplemental standards in 40 CFR 192.21 (f) may be applied if residual radionuclides other than Ra-226 and its decay products are present in sufficient quantity and concentration that they pose a significant radiation hazard. To determine whether the known Th-230 that was left on the processing site is a significant radiation hazard, the quantity was estimated and a health risk assessment was performed based on the available Th-230 information.

It is estimated that at least $1480 \mathrm{~m}^{3}$ of Th-230 remain on the site. The average concentration of the Th-230 is $234 \mathrm{pCi}$ per gram with a low value of $44 \mathrm{pCi}$ per gram and a high value of $650 \mathrm{pCi}$ per gram. The average radon flux of the Th-230 as calculated by the RAECOM model is $11.8 \mathrm{pCi} / \mathrm{m}^{2} / \mathrm{sec}$, with a low value of 2.8 $\mathrm{pCi} / \mathrm{m}^{2} / \mathrm{sec}$ and a high value of $56.9 \mathrm{pCi} / \mathrm{m}^{2} / \mathrm{sec}$. These radon flux values equate to an average indoor working level of 0.06 with a low value of 0.014 and a high value of 0.29 , assuming a slab-on-grade structure and 50 percent equilibrium between radon and its short-lived decay products. Table 6.1 provides the results of these calculations. The health risk analysis is discussed in detail in Section 6.2.1.

Because the Vitro site is in an industrial area zoned for commercial use, future home construction is not likely. The property owner's long-term plan for the site is to expand the water treatment facility currently on the adjacent vicinity property. Until then, the near-term plan is to construct a golf course on the site. Because the Th-230 lens is not expected to be greater than $2 \mathrm{ft}(0.6 \mathrm{~m})$ thick, any future excavation will mix the contamination with clean materials and dilute the concentration.

Effects on ground water quality are expected to be negligible because the Th-230 appears to be in the insoluble hydroxide form, which is not mobile. Available water quality analyses indicate the Th-230 and chemical-contaminant concentrations do not exceed proposed EPA ground water standards. Under the UMTRA Ground Water Project, the DOE will further evaluate ground water conditions at the Vitro site and take any action required to ensure compliance with the appropriate standards.

Based on the results of the health risk assessment, the Th-230 that is present on the Vitro processing site meets the requirement for applying supplemental standards. Therefore, additional remediation should not be necessary. To ensure the current and future land owners are aware of the contamination that was left on the Vitro site, the DOE will transmit the information contained in this section to the state of Utah and to the current property owner under a separate cover. When DOE issues land annotation regulations, the state of Utah will be required to annotate the land records with this information. 


\section{Table 6.1 Grids exceeding $35 \mathrm{pCi}$ per gram}

\begin{tabular}{|c|c|c|c|c|c|c|}
\hline \multicolumn{2}{|c|}{ Grid location } & \multirow{2}{*}{$\begin{array}{c}\text { Th-230 } \\
\text { (pCi per gram) }\end{array}$} & \multirow{2}{*}{$\begin{array}{c}\text { Ra-226 } \\
\text { (pCi per gram) }\end{array}$} & \multirow{2}{*}{$\begin{array}{c}\text { Ra-226 in } \\
1000 \text { years } \\
\text { (pCi per gram) }\end{array}$} & \multirow{2}{*}{$\begin{array}{l}\text { Fill depth } \\
\text { (ft) }\end{array}$} & \multirow{2}{*}{$\begin{array}{l}\text { Rn-222 flux } \\
\left(\mathrm{pCi} / \mathrm{m}^{2} / \mathrm{s}\right)\end{array}$} \\
\hline North & East & & & & & \\
\hline \multicolumn{7}{|c|}{ Area 1 - southwest corner } \\
\hline 429 & $429^{a}$ & 650.0 & 3.1 & 229.4 & 6.1 & 24.9 \\
\hline \multicolumn{7}{|c|}{ Area 2 - Vitro ditch } \\
\hline 1089 & 099 & 60.2 & 5.4 & 24.6 & 5.0 & 3.6 \\
\hline 990 & 066 & 90.3 & 5.3 & 35.0 & 5.9 & 3.8 \\
\hline 1056 & 066 & 166.0 & 11.0 & 65.1 & 4.9 & 7.3 \\
\hline 1122 & 066 & 213.0 & 9.0 & 80.4 & 3.8 & 12.4 \\
\hline 1188 & 066 & 361.0 & 5.8 & 130.1 & 2.1 & 37.3 \\
\hline \multicolumn{7}{|c|}{ Area 3 - north-central evaporation pond } \\
\hline $1353^{b}$ & 132 & 380.0 & 3.4 & 135.1 & 4.9 & 14.8 \\
\hline $1353^{b}$ & 297 & 330.0 & 5.1 & 118.8 & 5.5 & 10.9 \\
\hline 990 & 693 & 85.0 & 1.7 & 30.8 & 4.7 & 4.5 \\
\hline 1122 & 858 & 400.0 & 5.1 & 143.3 & 0.5 & 56.9 \\
\hline 1320 & 1023 & 51.0 & 2.1 & 19.2 & 2.2 & 5.5 \\
\hline 1386 & 924 & 390.0 & 5.5 & 140.0 & 3.6 & 22.0 \\
\hline \multicolumn{7}{|c|}{ Area 4 - evaporation pond } \\
\hline 891 & 1089 & 84.0 & 2.2 & 30.8 & 3.8 & 5.5 \\
\hline 1122 & 1221 & 240.0 & 6.4 & 88.1 & 1.4 & 27.0 \\
\hline 363 & 2178 & 60.0 & 1.7 & 22.1 & 2.9 & 5.2 \\
\hline $627^{\mathrm{b}}$ & 2178 & 44.0 & 3.0 & 17.3 & 5.0 & 2.8 \\
\hline 627 & 2145 & 320.0 & 4.3 & 113.7 & 7.0 & 7.2 \\
\hline 660 & 2145 & 410.0 & 5.4 & 147.0 & 7.0 & 8.9 \\
\hline 660 & 2178 & 200.0 & 2.2 & 71.4 & 6.9 & 5.1 \\
\hline 726 & 2046 & 129.0 & 2.9 & 47.0 & 3.0 & 9.6 \\
\hline $759^{b}$ & 2145 & 300.0 & 4.3 & 107.8 & 6.7 & 7.3 \\
\hline $759^{b}$ & 2112 & 360.0 & 4.4 & 128.8 & 8.5 & 5.5 \\
\hline $825^{b}$ & 2079 & 228.0 & 5.4 & 83.3 & 7.4 & 5.1 \\
\hline 924 & 1947 & 52.5 & 2.3 & 19.9 & 4.8 & 3.3 \\
\hline
\end{tabular}

${ }^{3}$ This point represents a westing coordinate; all others represent an easting coordinate as indicated by the column heading.

b Thorium data for these grids were collected after the initial verification sampling. 


\subsubsection{Health Risk Assessment}

\section{Site Th-230 data analysis}

Any Th-230 concentration that is less than $35 \mathrm{pCi}$ per gram is considered to meet the EPA cleanup standard for Ra-226. This limit was determined by estimating how much Th-230 would produce $16.5 \mathrm{pCi}$ per gram (15 $\mathrm{pCi}$ per gram plus background) Ra-226 in 1000 years when the current Ra-226 concentration is less than or equal to $6.5 \mathrm{pCi}$ per gram.

Table 6.1 gives the location coordinates, sample Ra-226 concentration, sample Th-230 concentration, projected 1000-year Ra-226 concentrations, the depth of uncontaminated fill placed over a grid location, and projected 1000 -year radon flux for samples with Th- 230 concentrations greater than $35 \mathrm{pCi}$ per gram. The maximum observed Th-230 concentrations were $410 \mathrm{pCi}$ per gram in the pond area and $650 \mathrm{pCi}$ per gram in the southwest corner area.

Figure 6.1 shows the locations of the known contaminated areas. The Vitro ditch area, designated as area 2 in Figure 6.1, was the only section of the ditch characterized by the additional Th-230 analysis of verification samples. This figure also illustrates the entire Vitro ditch. Because similar geochemical characteristics exist across the site, the remainder of the ditch would be expected to exhibit similar Th-230 contamination.

\section{RAECOM analysis}

The radon flux produced by the Th- 230 contaminated areas was estimated using the RAECOM computer code. RAECOM was run for each area with an unsaturated backfill layer and a saturated contaminated area.

RAECOM requires seven input parameters. The following input parameters were obtained from the MK-F report on vicinity property SL-018S (MK-F, 1988) and the NRC guideline:

- Unsaturated backfill layer moisture content of 6 percent and radon diffusion coefficient of 0.020 centimeters squared per second $\left(\mathrm{cm}^{2} / \mathrm{s}\right)$.

- Saturated contaminated layer moisture content of 15 (contaminated lens) and 24 (foundation) percent and radon diffusion coefficient of 0.007 and $0.0001 \mathrm{~cm}^{2} / \mathrm{s}$, respectively.

- Bülk density of 1.60 grams per $\mathrm{cm}^{3}$ for all layers.

- Porosity of 0.40 for all layers.

In addition, the ambient radon concentration was assumed to be $0.5 \mathrm{pCi} / \mathrm{L}$ and the flux into the bottom layer was assumed to be $0 \mathrm{pCi} / \mathrm{m}^{2} / \mathrm{s}$. The site-specific emanating fraction of Rn-222 produced from Th-230 decay is not available. Literature suggests 
that the emanating fraction would be similar to or less than that from Ra-226 decay. An emanating fraction of 0.3 was assumed, based on information in NUREG (1979) and NRC (1989). All Th-230 remaining on the site is assumed to remain in the saturated zone. This assumption is made because excavation over most of the site reached a depth where saturated conditions were present. In addition, the Th-230 lens is estimated to be $2 \mathrm{ft}(0.6 \mathrm{~m})$ thick. This estimation was determined based on remediation of an adjacent property, SL-018. Because of the proximity of this property to the Vitro site and because it is believed the evaporation pond probably extended onto this property, this property is expected to exhibit similar Th-230 contamination and geochemical characteristics as the site evaporation pond. On SL018 the Th-230 generally consisted of a thin lens approximately $2 \mathrm{ft}(0.6 \mathrm{~m})$ thick.

The projected Ra-226 concentration for each of the four areas was determined for Ra-226 ingrowth over 1000 years. The 40 CFR 192 standards reference a 1000-year design life for "designated processing or depository sites under Section 108 of the Uranium Mill Tailings Radiation Control Act of 1978" (42 USC $\$ 7901$ et seq.). After 1000 years, the Ra-226 concentration would be 35.2 percent of the present Th-230 concentration plus 64.8 percent of the Ra-226 concentration remaining following remedial action. RAECOM analyses showed that the highest radon flux in the Vitro ditch area following remedial action would be $37.3 \mathrm{pCi} / \mathrm{m}^{2} / \mathrm{s}$ in 1000 years. A similar calculation for the north-central area following remedial action would produce a radon flux of $56.9 \mathrm{pCi} / \mathrm{m}^{2} / \mathrm{s}$.

\section{Impact analysis for a hypothetical structure}

Radon concentration in a hypothetical structure built over a Ra-226 deposit is given in Appendix J of NUREG (1979) by:

$$
C=F A B /(V R \times 1000)
$$

Where:

$$
\begin{aligned}
& C=\text { Rn-222 concentration }(\mathrm{pCi} / \mathrm{L}) \\
& F=\text { Rn-222 flux }\left(\mathrm{pCi} / \mathrm{m}^{2} / \mathrm{s}\right) \\
& A=\text { Area over which flux enters }\left(\mathrm{m}^{2}\right) \\
& B=\text { Flux reduction factor in entering structure } \\
& V=\text { Volume of structure }\left(\mathrm{m}^{3}\right) \\
& R=\text { Effective } R n-222 \text { removal rate }\left(\mathrm{s}^{-1}\right)
\end{aligned}
$$

The coefficients used in the analysis were:

$$
\begin{aligned}
& F=37 \mathrm{pCi} / \mathrm{m}^{2} / \mathrm{s} \text { for Vitro ditch and } 57 \mathrm{pCi} / \mathrm{m}^{2} / \mathrm{s} \text { for north central area } \\
& A=103 \mathrm{~m}^{2} \\
& B=0.5 \\
& V=250 \mathrm{~m}^{3} \\
& R=1.98 \mathrm{E}-4 \mathrm{~s}^{-1} \text { (one air change per } 1.4 \text { hour). }
\end{aligned}
$$


Radon-222 flux (F) for each area was calculated by RAECOM. The flux reduction factor $(B)$ is a fairly conservative value (NUREG, 1979). The effective $R n-222$ removal rate $(R)$ is conservatively based on information in ICRP (1979).

Slab-on-grade construction was assumed for the structure, based on the depth-to-ground water information. Basements are not common in the area and would be unlikely due to the shallow ground water conditions. Radon escaping from the contaminated material layer must diffuse first through the saturated soil layer and then through the unsaturated backfill layer.

\section{Results}

Results indicate that when excavated to the level of the saturated zone and backfilled to a depth of $2.1 \mathrm{ft}(0.6 \mathrm{~m})$, a residual Th-230 concentration of $361 \mathrm{pCi}$ per gram and a radium concentration of $5.8 \mathrm{pCi}$ per gram in the Vitro ditch area would produce a radon flux of $37 \mathrm{pCi} / \mathrm{m}^{2} / \mathrm{s}$ in 1000 years. This radon flux would produce an indoor working level (WL) of 0.19 in a hypothetical slab-on-grade structure, assuming 50 percent equilibrium between radon and its short-lived decay products. A residual Th-230 concentration of $400 \mathrm{pCi}$ per gram and a radium concentration of $5.1 \mathrm{pCi}$ per gram in the north central area and a backfill depth of $0.5 \mathrm{ft}(0.15 \mathrm{~m})$ would produce a radon flux of $57 \mathrm{pCi} / \mathrm{m}^{2} \mathrm{~s}$ and an indoor WL of 0.29 in 1000 years.

A scenario for possible health impacts is one where future construction activities bring the contaminated material to the ground surface. The Th-230 contaminated material would then be available for dispersion by both natural and human forces. Possible pathways for human exposure would then be inhalation of airborne radioactive particulates and radon daughters and direct gamma radiation. If the material were excavated after being backfilled, the contaminated material would be diluted by the volume of clean fill covering the deposit. Mixing the contaminated material with clean fill would lower the projected Ra-226 concentration. The resulting concentrations should not be significantly greater than the EPA standard for Ra-226 in surface soil 15 pCi per gram) and probably would be below the standard for subsurface soil (15 pCi per gram). Therefore, the possible health impacts from excavation of the contaminated material would not be excessive. To "bracket" potential health impacts from the various Th-230-contaminated areas, five RESRAD scenario computer calculations were conducted for radiation doses that a worker or shopkeeper in a light industrial shop constructed over the areas might receive 1000 years from today. At that time, some Ra-226 will have grown in from decaying Th-230. Values of Th-230 from Table 6.1 were selected as possible inputs; Table 6.2 presents the results of those calculations. Two additional scenarios were run to estimate the potential exposure that a future construction worker might receive while building a structure on the property. They were assumed to work for a period of 3 months on either the "average" grid, or the highest Th-230 concentration grid $(429 \mathrm{~N}-429 \mathrm{~W})$. The projected exposures were 26 millirem (mrem)/3 months for the "average" grid and $71 \mathrm{mrem} / 3$ months for the highest grid. 
Table 6.2 1000-year radiation dose projections from selected Th-230 grids

\begin{tabular}{ccccc}
\hline Grid & $\begin{array}{c}\text { Th-230 } \\
\text { (pCi per gram) }\end{array}$ & $\begin{array}{c}\text { Ra-226 } \\
\text { (pCi per gram) }\end{array}$ & $\begin{array}{c}\text { Backfill depth } \\
\text { (ft) }\end{array}$ & $\begin{array}{c}\text { mrem/year } \\
\text { @1000 years }\end{array}$ \\
\hline $627 \mathrm{~N}-2178 \mathrm{E}$ & 44.0 & 3.0 & 5.0 & 83 \\
"avg. of 24" & 233.5 & 4.4 & 4.6 & 390 \\
429N-429W & 650. & 3.1 & 6.1 & 544 \\
$1122 \mathrm{~N}-858 \mathrm{E}$ & 400. & 5.1 & 0.5 & 1206 \\
$429 \mathrm{~N}-429 \mathrm{~W}$ & 650 & 3.1 & 0.0 & 2119 \\
\hline
\end{tabular}

Based on the results of the radon flux calculations discussed earlier, and the results of the RESRAD calculations, it is important that future users of the site are aware of the presence of residual contamination. For comparison, the National Council on Radiation Projection and Measurements in Report No. 93 estimates the total average dose to United States residents is about $300 \mathrm{mrem} /$ year (NCRP, 1987). By taking appropriate radiological measurements during excavation and construction, the actual lateral and vertical extent and concentration of the contaminants can be determined and appropriate mitigative measures (if necessary) can be taken. The scenarios modeled assume the contaminated layer is $2 \mathrm{ft}(0.6 \mathrm{~m})$ thick, which may or may not be the case, since this assumption was based on data obtained on an adjacent vicinity property and was not confirmed by any measurements on the Vitro site.

A future inhabitant of the site could drill a shallow well to obtain drinking water. This scenario is unlikely because of the available municipal sources of drinking water. As discussed in the final EIS, shallow ground water is not the primary source for domestic, municipal, or industrial water supplies in the Salt Lake City area because of the insufficient quantity or poor chemical quality of the water (DOE, 1984a). 


\subsection{STATEMENT OF CERTIFICATION}

The last of the tailings material was removed from the Vitro site on 20 November 1987 . The Vitro site in South Salt Lake is bounded by 3300 South Street on the south, Roper railroad yard on the east, 900 West Street on the west, and Mill Creek on the north. The CVWRF occupies the northern half of the site. The CVWRF was not part of the Vitro mill that was on the site, but was contaminated by material from the mill site.

Verification of the site involved dividing the site into more than five thousand $33 \times 33-\mathrm{ft}$ (10 $\times 10-\mathrm{m}$ ) grids. Direct oversight by UBRC staff was continual, for all hours of operation. Excavation continued until the clean interface level was located. This level then was marked by the UBRC technician on the site. The contractor cleaned to this level, ensuring that all material above this level was removed. Due to the type of equipment used to clean up the tailings materials, overexcavation up to $1 \mathrm{ft}(0.3 \mathrm{~m})$ was considered acceptable. However, on-site UBRC staff tried to keep the level of overexcavation to 6 inches $(150 \mathrm{~mm})$ or less. Cleanup was monitored by the UBRC staff with handheld instruments and the initial removal was guided by measurements taken during excavation. Final verification measurements then were taken to ensure that the floor of the excavation was clean. More than 14,000 samples were analyzed to ensure that more than 5000-plus grids were cleaned to the levels required under UMTRA guidelines.

Most of the construction drawings have at least one partial grid that might be missing data. In almost all cases, the problem is at the edge of the property. All the grids were laid out to cover the entire site as far as it could be determined. The existence of a grid square does not mean that contamination on the area is represented by the drawing. The work progressed from known contaminated areas to the edge of the property and the end of tailings. All of the contamination did not stop exactly on the property line. Vicinity properties surrounded the site. Ditch beds were boundaries in some places and they did not always run exactly on a given line as drawn. When tailings or contamination ran out, data were gathered only to confirm the end had been reached. When the end of contamination was in the middle of a grid, excavation ended but the end of the tailings was not reflected by redrawing the grids. In some cases, two small bits of a grid were combined to try to enclose a standard grid size. In some cases, the partial grid was not addressed as shown on the drawing because the grid outlined the property line but not the property contamination.

In all cases, the depth of backfill exceeds limits for the 5-pCi per gram-plus-background standard, which is the only standard applicable for the Vitro site. Most of the grid squares were cleaned to the 5-pCi per gram limit, not because it was required but because the geology of the area made it almost impossible to do otherwise. The bottom of the Vitro mill site is an ancient lake bed and removing the contaminated material required excavation to that level. Permeation into the lake bed was a matter of fractions of inches for most of the site. For example, at a given depth of excavation, contamination could be $200 \mathrm{pCi}$ per gram of Ra-226, yet at 1 inch $(25 \mathrm{~mm})$ deeper the level would be $1.9 \mathrm{pCi}$ per gram. The nature of the project and the speed for verification did not allow restructuring the drawings to conform to exact conditions of each grid.

The record drawings show a number of grid blocks with no certified cleanup values listed. Justifications for the lack of information in each grid block are shown in Table 7.1. 
Table 7.1 Grids that fail acceptance criteria or are missing data verifying cleanup conditions

\begin{tabular}{lccccc}
\hline Grid identification & $\begin{array}{l}\text { Ra-226 } \\
\text { (actual) }\end{array}$ & $\begin{array}{c}\text { Backfill } \\
\text { (ft) }\end{array}$ & $\begin{array}{c}\text { Ra-226 } \\
\text { (calc.) }\end{array}$ & $\begin{array}{c}\text { Backfill } \\
\text { (calc.ft.) }\end{array}$ & Comments \\
\hline
\end{tabular}

Drawing SLC-CL-0022

$13+20 \mathrm{~N}-0+00 R T$ " $\mathrm{B}$ "

Drawing SLC-CL-0023

$$
\begin{aligned}
& 5+28 N-0+99 " B " \\
& 3+96 N-1+32 "
\end{aligned}
$$

Drawing SLC-CL-0024

$$
\begin{aligned}
& 13+20-8+58 W W^{\prime A "} \\
& 12+87-264 W \\
& 12+54-6+93 W "
\end{aligned}
$$

Drawing SLC-CL-0025

$$
11+22-8+58 W \text { "A" }
$$

Drawing SLC-CL-0028

$$
\begin{aligned}
& 25+08-8+58 E \text { "A" } \\
& 24+42-8+91 E " \\
& 25+41-8+25 E "
\end{aligned}
$$

7.6

0.4

N/A

4.3

$-0.3$

N/A

N/A

0

1.72

N/A

N/A

3.9

$a, e$

7.0

0

0.8

N/A

3.9

a,e
4.4

$a, e$

N/A

N/A

b

N/A

N/A

f

Drawing SLC-CL-0029

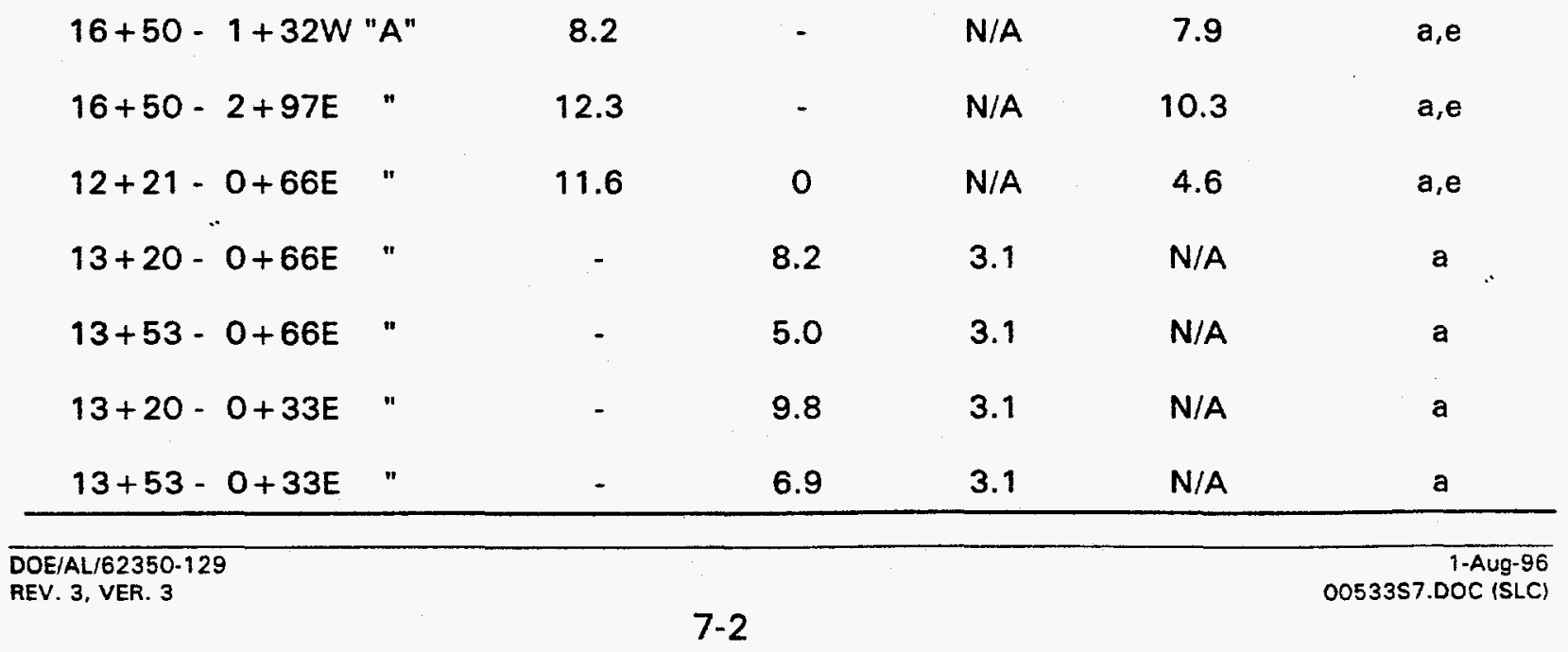


Table 7.1 Grids that fail acceptance criteria or are missing data verifying cleanup conditions (Continued)

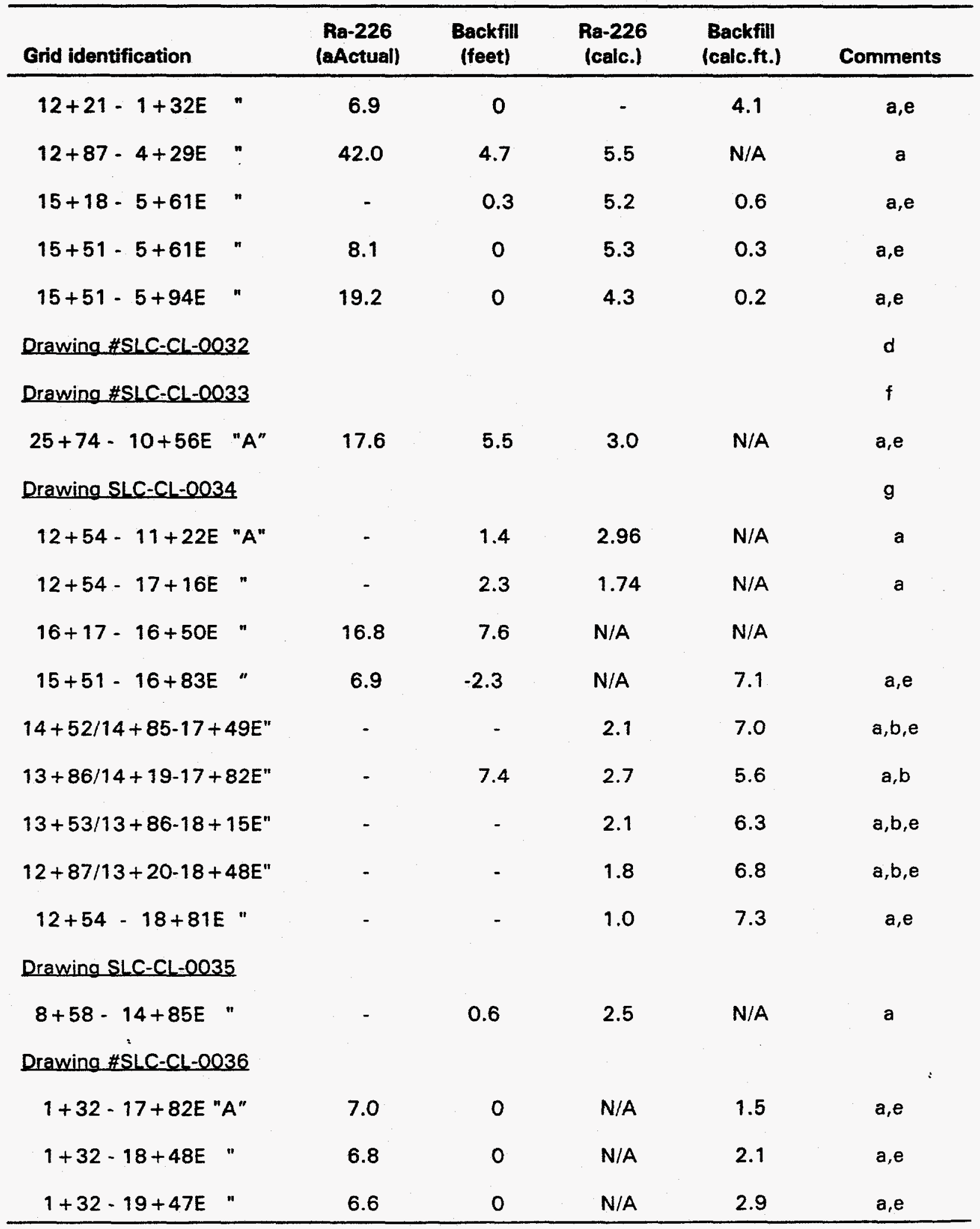


Table 7.1 Grids that fail acceptance criteria or are missing data verifying cleanup conditions (Concluded)

\begin{tabular}{|c|c|c|c|c|c|}
\hline Grid identification & $\begin{array}{l}\text { Ra-226 } \\
\text { (actual) }\end{array}$ & $\begin{array}{c}\text { Backfill } \\
\text { (feet) }\end{array}$ & $\begin{array}{c}\text { Ra-226 } \\
\text { (calc.) }\end{array}$ & $\begin{array}{l}\text { Backfill } \\
\text { (calc.ft.) }\end{array}$ & Comments \\
\hline \multicolumn{6}{|l|}{ Drawing \#SLC-CL-0037 } \\
\hline $6+93-22+11 E$ "A" & - & - & 3.15 & 5.95 & $a, e$ \\
\hline $8+58-21+12 E$ & - & 8.0 & 3.45 & N/A & a \\
\hline $9+57-20+46 E$ & - & 3.6 & 1.72 & N/A & a \\
\hline $10+89-19+80 E$ & - & - & 3.37 & 6.82 & $a, e$ \\
\hline \multicolumn{6}{|l|}{ Drawing \#SLC-CL-0038 } \\
\hline $5+28-20+79 E$ "A" & - & 0.3 & 1.72 & 4.2 & $a, e$ \\
\hline $5+28-21+12 E$ & - & 3.6 & 2.45 & N/A & a \\
\hline
\end{tabular}

Comments for Table $\mathbf{7 . 1}$ that identify grids missing data pertaining to extent of contamination:

a. Calculated Ra-226 concentrations and backfill levels were determined by averaging known concentrations and known backfill levels from grids adjacent to the grid with missing data. When adjacent grids did not provide the required information, data from the next closest grids were used to calculate the missing information. Only known concentrations were used to determine averages assigned to the grids with missing information.

b. Grids and partial grids combined to equal $100 \mathrm{~m}^{2}$ for sampling.

c. In the center of the drawing containing this grid, data apparently are missing on the south side of Vitro ditch. In reality, cleanup at the ditch area was accomplished by chasing the tailings south to the banks of Vitro ditch; then the ditch was moved to the north and its new path was laid down in clean backfill. Later, tailings were chased from south to north until the remediation had removed all the material up to the backfill material placed during remediation from the north. The drawings do not show the actual interface between the . locations, but the north boundary and the south boundary lined from the two separate grid groups actually overlap the grids at the indicated Vitro ditch interface. It was decided that redrawing the grids and joining the grids might be more confusing than leaving them as they were already drawn. No grids were overlooked and all areas were remediated. 
d. The end of the dig did not always extend to the outside edge of the grid as drawn. In almost all cases, the perimeter of the site is shown as a straight line right to the end of the grid; however, the tailings did not extend completely across the grid. No effort was made to draw the end of remediation to scale. Some grids appear to be missing data, but in reality are outside the area of excavation.

e. Backfill elevations were documented for payment of the work. Therefore when backfill elevations indicate less than 6 inches, it is because the state did not perform the backfill activities. Members of the UBRC staff that worked on the project are willing to testify that all areas of the site were backfilled with a minimum of 6 inches $(150 \mathrm{~mm})$ of fill after excavation was finished. Some of these areas were left open for a period of time so that CVWRF could do the required work but the areas were backfilled to a uniform level when the work was completed. In addition, the areas identified as having zero inches of backfill were visited by UBRC staff during July 1993. Twenty-five test holes were dug to a depth of 12 inches $(300 \mathrm{~mm})$ at random locations over the site and backfill material filled all of these holes. In addition, most of the areas in this drawing that indicate " $O$ " of backfill are now covered with grass. The CVWRF staff informed the UBRC that at least 6 inches $(150 \mathrm{~mm}$ ) of backfill (topsoil) were placed on existing grade prior to landscaping.

f. The property line on the east side of the property in some cases extends onto adjacent vicinity property and additional cleaning at this junction was accomplished by cleaning from the vicinity property toward the Vitro property until contact with backfill material that was placed during the remediation effort. The edge of construction does not necessarily follow property lines.

g. Data referring to partial grids north of $16+50$ between $8+91 E$ and $12+87 E$ can be found on Drawing SLC-CL-0038B. Information for grids $12+54 E$ to $16+50$ through $18+48$ can be found on drawing SLC-CL-0038B. 
A comment column in Table 7.1 deals with special conditions of that grid or that particular drawing. In some cases, it may reference other drawings or other methods used to verify conditions at the site. Note that missing grid information that did not appear to be needed was not provided. For example, if a grid were missing depth of backfill information but the concentration was less than $5 \mathrm{pCi}$ per gram of Ra-226, the grid information was not provided. If a grid were missing both Ra-226 concentration data and depth of backfill data, only the concentration as averaged by adjacent area grids was provided, if less than $5 \mathrm{pCi}$ per gram Ra-226 was determined.

The comment column may indicate that some grids were not cleaned because they were at the end of the dig, or that they were part of other grids. Notwithstanding all of the calculations to determine conditions at the Vitro site, three additional walkover surveys were conducted in site locations where information appears to be missing, as well as across the entire facility from east to west in five random passes to verify exposure levels. Except for one spot that was at 24 microR per hour at contact (crossover of the Vitro ditch) in the westcentral portion of the site, all measurements indicated normal background levels for Salt Lake Valley.

Due to the extensive amount of verification samples taken, the constant oversight by the UBRC staff, and follow-up gamma surveys of the site, the UBRC is confident that cleanup of the Vitro site complies with all UMTRA criteria for certification and that only minimal tailings material is left on the site, if any.

Supplemental standards were used when radionuclides other than Ra-226 were encountered (i.e., Th-230) and when safety was a primary concern. Upon considering the risk of removal due to natural or manmade hazards, and the risk to transportation systems, the state of Utah made a final decision to initiate supplemental standards. To accomplish this, the UDOT and UBRC examined each location where supplemental standards were proposed. (For supplemental standards criteria see Section 6.0.) Upon determining that further work in a given area was unsafe, that removal of tailings would weaken various nonreplaceable structures, or that future exposures would not increase by leaving tailings in place, the areas were documented and the UBRC approved bypassing these areas. Supplemental standards were applied to all proposed locations in accordance with criteria established under UMTRA Project guidelines.

In addition to the areas where supplemental standards were applied, six grids exceed the Ra-226 concentration limit of $15 \mathrm{pCi}$ per gram + background. The reported values are 42.0, 28.1, 19.2, 17.9, 17.6, and 16.8. These elevated grids were identified after the site had been backfilled. Due to the geology of the site and the way excavation was performed it is believed that any contamination remaining on these grids is confined to a very thin lens or randomly distributed spots. Locating and removing this contamination would be virtually impossible. An analysis of the projected radon flux from the grid with $42 \mathrm{pCi}$ per gram of Ra-226 was performed. This analysis projects a radon flux of $3.7 \mathrm{pCi} / \mathrm{m}^{2} / \mathrm{s}$, which would produce 0.02 radon working levels if a hypothetical slab-on-grade house were built on the grid. These elevated grids are not considered health hazards because of their relatively low radioactivity and small quantity. Therefore these grids will remain in place. 
All the record drawings in Appendix $A$ of the Vitro site shown in "UMTRAP, Uranium Mill Tailings Remedial Action Project, Salt Lake City, Utah," construction drawing set (rev. 10-1-89) "Record Drawing," are certified by the state of Utah to be in accordance with DOE UMTRA cleanup criteria.

\subsection{REGULATORY CONTACTS}

The Vitro site was one of the first UMTRA sites designed and remediated. Under DOE and NRC guidelines, the regulation governing remedial action at Vitro was the UMTRCA of 1978 (42 USC $\$ 7901$ et seq.). The state, federal, and local authorities listed below were contacted about coordinating their regulations with the UMTRCA.

- Salt Lake County Health Department.

- South Salt Lake City Police Department.

- Utah Department of Natural Resources.

- Utah Department of Transportation.

- Utah Department of Public Safety (Highway Patrol).

- Salt Lake County Public Works Department.

- Utah Department of Health, Bureau of Water Pollution Control and Bureau of Air Quality.

- Utah Occupational Safety and Health Administration.

- Utah Department of Health, Utah Bureau of Radiation Control (Utah Division of Radiation Control - new division title as of 1992).

\subsection{FUTURE LAND USE}

Since ground water compliance as mandated by 40 CFR Part 192 has not been demonstrated, use of the Vitro processing site by the landowner, CVWRF, must be restricted. Land use restrictions will be in effect to ensure that future development activities do not hinder access to the site, aggravate the present contaminant conditions, preclude ground water compliance actions from being performed, or disturb/alter any wells or monitoring devices that have been installed. The DOE's authority to restrict use of this property is stated in Section IV.B(b) of RAA Number DE-R004-83AL22142, between the DOE, the state of Utah, and CVWRF, whereby the DOE has the right to restrict access to the Vitro processing site to facilitate remedial action, and to protect and ensure public health and safety. This clause is in effect until the UMTRA Ground Water Project for this site has been certified as complete by the NRC. To ensure land use restrictions are followed, all proposed plans for development of the Vitro processing site must be approved by the DOE. 


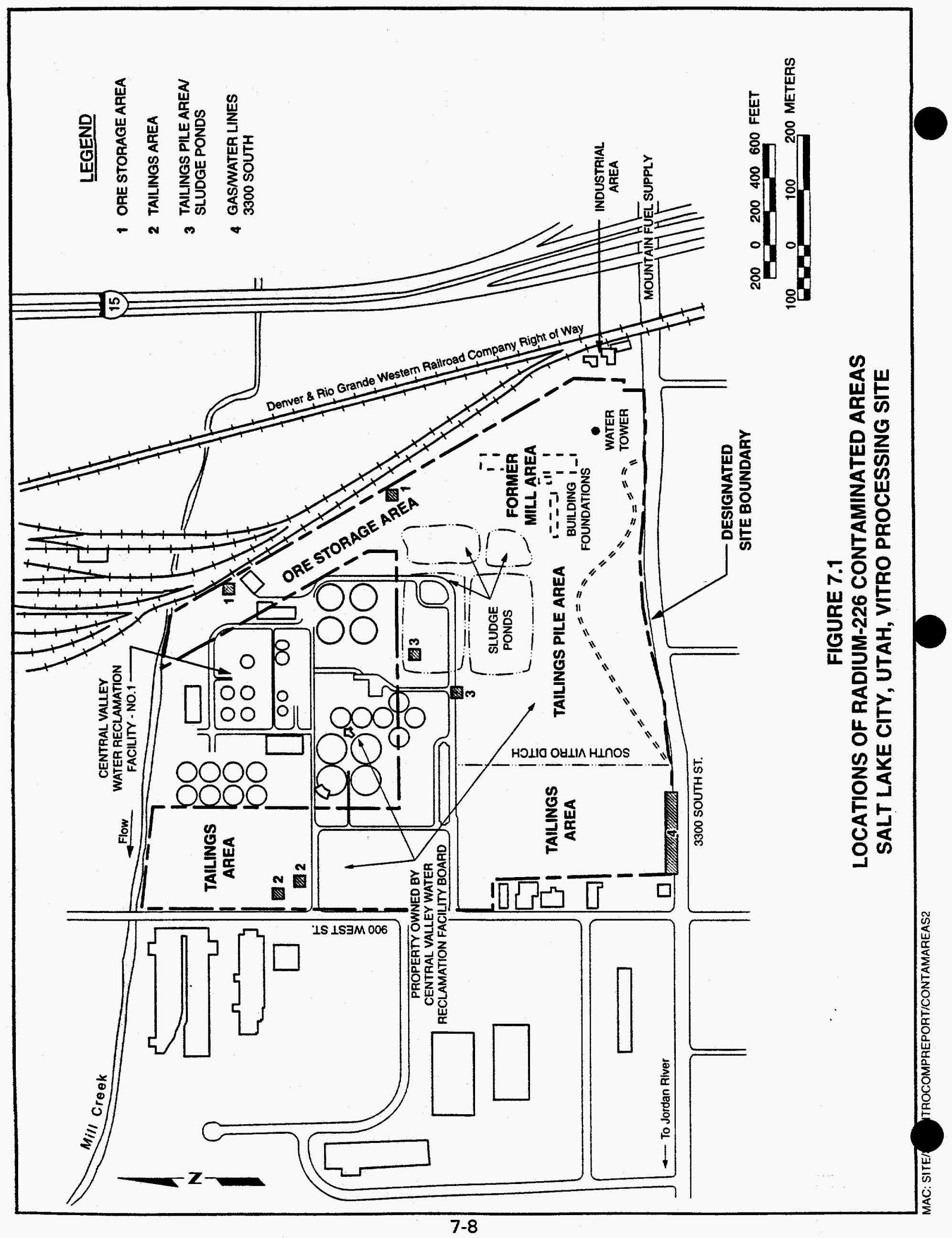




\subsection{REFERENCES}

DOE (U.S. Department of Energy), 1995. Vicinity Property Completion Report at SL-067S, Central Valley Water Reclamation Facility, Salt Lake City, Utah, January 1995, U.S. Department of Energy, UMTRA Project Office, Albuquerque Operations Office, Albuquerque, New Mexico.

DOE (U.S. Department of Energy), 1984a. Final Environmental Impact Statement of Remedial Actions at the Former Vitro Chemical Company Site, South Salt Lake, Salt Lake County, Utah, DOE/EIS-0099-F, Vols. 1 and 2, July, U.S. Department of Energy, UMTRA Project Office, Albuquerque Operations Office, Albuquerque, New Mexico.

DOE (U.S. Department of Energy), 1984b. Remedial Action Plan and Site Conceptual Design for Stabilization of the Inactive Uranium Mill Tailings Site at Salt Lake City, Utah, UMTRA-DOE/EA-0141.0000, U.S. Department of Energy, UMTRA Project Office, Albuquerque Operations Office, Albuquerque, New Mexico.

DOE (U.S. Department of Energy), 1984c. Processing Site Characterization Report for the Uranium Mill Tailings Site at Salt Lake City, Utah, UMTRA-DOE/AL-05102.0000, December, U.S. Department of Energy, UMTRA Project Office, Albuquerque Operations Office, Albuquerque, New Mexico.

FBDU (Ford, Bacon \& Davis Utah Inc.), 1981. Engineering Assessment of Inactive Uranium Mill Tailings, DOE/UMT-0102, April 1981, U.S. Department of Energy, UMTRA Project, Office, Albuquerque Operations Office, Albuquerque, New Mexico, prepared by Ford, Bacon \& Davis Inc., Salt Lake City, Utah.

Hintze, L. F. and A. W. Miller, 1975. Hydrological Study of Vitro Site, unpublished report, prepared for Ford, Bacon and Davis, Utah, Salt Lake City, Utah, for the U.S. Department of Energy, UMTRA Project Office, Albuquerque Operations Office, Albuquerque, New Mexico.

ICRP (International Commission on Radiological Protection), 1979. Lung Cancer Risk from Indoor Exposure to Radon Daughters, ICRP Publication 50, Pergamon Press, Elmsford, New York.

MK-F (Morrison Knudsen-Ferguson Company), 1988. Radiological and Engineering Assessment, Appendix E, Thorium Deposit Characterization and Impact Assessment Vicinity Property, SL-018S, Rev. 1, Vol. 2 of 2, March, prepared by Morrison Knudsen-Ferguson Company for the U.S. Department of Energy, UMTRA Project Office, Albuquerque Operations Office, Albuquerque, New Mexico.

NCRP (National Council on Radiation Protection and Measurement), 1987. "Ionizing Radiation Exposure of the Population of the United States," NCRP Publication 93, NCRP, Bethesda, Maryland. 
NRC (U.S. Nuclear Regulatory Commission), 1989. Calculation of Radon Flux Attenuation by Earthen Uranium Mill Tailings Covers, Regulatory Guide 3.6.4, Office of Nuclear Regulatory Research, U.S. Nuclear Regulatory Commission, Washington, D.C.

NUREG (U.S. Nuclear Regulatory Commission), 1984. Radon Attenuation Handbook for Uranium Mill Tailings Cover Design, NUREG/CR-3533, April 1984, Office of Nuclear Regulatory Research, U.S. Nuclear Regulatory Commission, Washington, D.C.

NUREG (U.S. Nuclear Regulatory Commission), 1979. "Draft Generic Environmental Impact Statement on Uranium Milling," NUREG-0511, April 1979, Office of Nuclear Regulatory Research, U.S. Nuclear Regulatory Commission, Washington, D.C.

SH\&B (Sergent, Hauskins \& Beckwith), 1983. Evaluation of Potential Earthquake Effects on Vitro Site, Salt Lake City, Utah, May, U.S. Department of Energy, UMTRA Project Office, Albuquerque Operations Office, Albuquerque, New Mexico, prepared by Sergent, Hauskins \& Beckwith, Phoenix, Arizona.

\section{U.S. CODE OF FEDERAL REGULATIONS}

10 CFR Part 20, Standards for Protection Against Radiation.

40 CFR Part 192, Health and Environmental Protection Standards for Uranium and Thorium Mill Tailings, U.S. Environmental Protection Agency.

\section{UNITED STATES CODE}

42 USC $\$ 7901$ et seq., Uranium Mill Tailings Radiation Control Act, 8 November 1978. 